\title{
Effect of elevation, season, and accelerated snowmelt on biogeochemical processes during isolated conifer needle litter decomposition
}

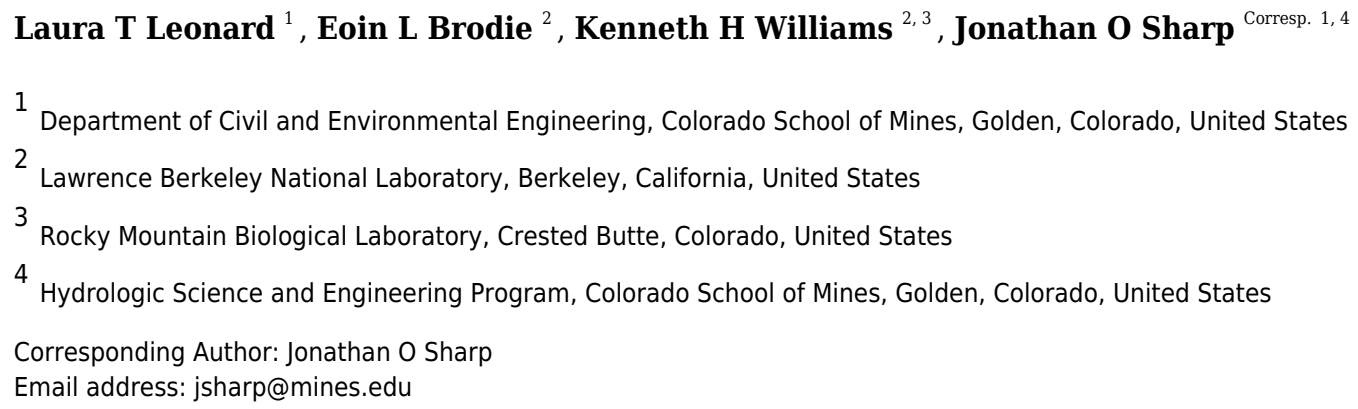

Increased drought and temperatures associated with climate change have implications for ecosystem stress with risk for enhanced carbon release in sensitive biomes. Litter decomposition is a key component of biogeochemical cycling in terrestrial ecosystems, but questions remain regarding the local response of decomposition processes to climate change. This is particularly complex in mountain ecosystems where the variable nature of the slope, aspect, soil type, and snowmelt dynamics play a role. Hence, the goal of this study was to determine the role of elevation, soil type, seasonal shifts in soil moisture, and snowmelt timing on litter decomposition processes. Experimental plots containing replicate deployments of harvested lodgepole and spruce needle litter alongside needle-free controls were established in open meadows at three elevations ranging from 2,800-3,500 meters in Crested Butte, Colorado. Soil biogeochemistry variables including gas flux, porewater chemistry, and microbial ecology were monitored over three climatically variable years that shifted from high monsoon rains to drought. Results indicated that elevation and soil type influenced baseline soil biogeochemical indicators; however, needle mass loss and chemical composition were consistent across the $700 \mathrm{~m}$ elevation gradient. Rates of gas flux were analogously consistent across a $300 \mathrm{~m}$ elevation gradient. The additional variable of early snowmelt by $2-3$ weeks had little impact on needle chemistry, microbial composition, and gas flux; however, it did result in increased dissolved organic carbon in lodgepole porewater collections suggesting a potential for aqueous export. In contrast to elevation, needle presence and seasonal variability of soil moisture and temperature both played significant roles in soil carbon fluxes. During a pronounced period of lower moisture and higher temperatures, bacterial community diversity increased across elevation with new members supplanting more dominant taxa. Microbial ecological 
resilience was demonstrated with a return to pre-drought structure and abundance after snowmelt rewetting the following year. These results show similar decomposition processes across a $700 \mathrm{~m}$ elevation gradient and reveal the sensitivity but resilience of soil microbial ecology to low moisture conditions. 


\section{Effect of elevation, season, and accelerated snowmelt 2 on biogeochemical processes during isolated conifer 3 needle litter decomposition}

4 Laura T. Leonard ${ }^{1}$, Eoin L. Brodie ${ }^{2}$, Kenneth H. Williams ${ }^{2,3}$, Jonathan O. Sharp ${ }^{1,4}$

$5{ }^{1}$ Department of Civil and Environmental Engineering, Colorado School of Mines, Golden, CO, 6 USA

$7 \quad{ }^{2}$ Lawrence Berkeley National Laboratory, Berkeley, CA, USA

$8 \quad{ }^{3}$ Rocky Mountain Biological Laboratory, Crested Butte, CO, USA

$9 \quad{ }^{4}$ Hydrologic Science and Engineering Program, Colorado School of Mines, Golden, CO, USA

10 Corresponding Author:

11 Jonathan O. Sharp ${ }^{1,4}$

12 Email address: jsharp@mines.edu 


\section{Abstract}

14 Increased drought and temperatures associated with climate change have implications for ecosystem stress with risk for enhanced carbon release in sensitive biomes. Litter decomposition is a key component of biogeochemical cycling in terrestrial ecosystems, but questions remain regarding the local response of decomposition processes to climate change. This is particularly complex in mountain ecosystems where the variable nature of the slope, aspect, soil type, and snowmelt dynamics play a role. Hence, the goal of this study was to determine the role of elevation, soil type, seasonal shifts in soil moisture, and snowmelt timing on litter decomposition processes. Experimental plots containing replicate deployments of harvested lodgepole and spruce needle litter alongside needle-free controls were established in open meadows at three elevations ranging from 2,800-3,500 meters in Crested Butte, Colorado. Soil biogeochemistry variables including gas flux, porewater chemistry, and microbial ecology were monitored over three climatically variable years that shifted from high monsoon rains to drought. Results indicated that elevation and soil type influenced baseline soil biogeochemical indicators; however, needle mass loss and chemical composition were consistent across the $700 \mathrm{~m}$ elevation gradient. Rates of gas flux were analogously consistent across a $300 \mathrm{~m}$ elevation gradient. The additional variable of early snowmelt by 2-3 weeks had little impact on needle chemistry, microbial composition, and gas flux; however, it did result in increased dissolved organic carbon in lodgepole porewater collections suggesting a potential for aqueous export. In contrast to elevation, needle presence and seasonal variability of soil moisture and temperature both played significant roles in soil carbon fluxes. During a pronounced period of lower moisture and higher temperatures, bacterial community diversity increased across elevation with new members supplanting more dominant taxa. Microbial ecological resilience was demonstrated with a return to pre-drought structure and abundance after snowmelt rewetting the following year. These results show similar decomposition processes across a $700 \mathrm{~m}$ elevation gradient and reveal the sensitivity but resilience of soil microbial ecology to low moisture conditions.

\section{Introduction}

41 Coniferous forests are at high risk of ecosystem stress as climate disturbances amplify globally productivity, and rhizospheric processes (Schlesinger et al., 2016) with potentially lasting implications for terrestrial organic matter cycling and associated microbial activity (Hyde et al., 2016; Negrón \& Cain, 2018). Hydrologic shifts associated with warming trends in snowdominated mountain environments, such as shorter periods of snow cover, have further implications for downstream water availability (Barnett, Adam \& Lettenmaier, 2005). Litter decomposition plays an important role in carbon and nitrogen cycling and can also be affected by drought conditions (Santonja et al., 2015). As a result, projected increases in global temperatures and shorter periods of snow cover could exasperate soil health and ecology in mountain ecoregions (de Vries et al., 2018). 
52 The North American Rocky Mountains largely consist of coniferous forests and the region has

53

54

55

56

57

58

59

60

61

62

63

64

65

66

67

68

69

70

71

72

73

74

75

76

77

78

79

80

81

82

83

84

85

86

87

88

89

90

91

observed a variety of climate change impacts. Rocky Mountain National Park reported a $1.9^{\circ} \mathrm{C}$ rise in average annual temperature in the last century with snow now melting 2-3 weeks earlier. Collectively these climate shifts have been associated with increased conifer tree mortality along with hydrologic implications for the Colorado River watershed (NPS, 2018). Moreover, a recent study identified biomes that harbored a heightened risk for organic carbon release from soils in association with climate change (Kramer \& Chadwick, 2018). Within the Rocky Mountains, these biomes include polar wet tundra and boreal wet forests that encompass montane and subalpine ecoregions of Colorado (GeoNetwork, 2007). Classifying sensitivity broadly by biome alone is limiting however due to the heterogeneity of local mountain terrain (Wainwright et al., 2020). Specifically, sensitivity to drought varies across locations with slope and aspect influencing energy balances and soil moisture (Körner, 2007). Soil type also can impact soil moisture and geochemical signatures (Lawrence \& Hornberger, 2007; Wilson et al., 2008) as well as the variability of snowpack dynamics across elevation that can play an additional role in drought responses across ecoregions (Tennant et al., 2017).

Soil microbial community responses to environmental stress additionally can influence decomposition and biogeochemical cycling processes. Within this study, we focus on different species of tree litter as the type of forest litterfall can affect associated microbial decomposition processes. Specifically, high quality litter typically defined by lower C:N ratios and higher bioavailability impact community composition by stimulating soil microorganisms and increasing decomposition rates (Šantrůčková, Krištůfková \& Vaněk, 2006; Fraterrigo, Ream \& Knoepp, 2018). Our past work determined that lodgepole litter was more bioavailable than spruce as evidenced by lower lignin-based aromatics and higher $\mathrm{CO}_{2}$ respiration rates after soil rewetting (Leonard et al., 2020a). Beyond the litter decomposition processes, soil conditions are known to affect microbial communities with reduced activity associated with low moisture conditions and in turn increased $\mathrm{CO}_{2}$ rates after rewetting of these soils (Birch, 1958; Schimel, 2018). The cause of this effect as it relates to microbial mechanisms and whether resilience to drought drives these observations is not fully understood. Recent studies have shown microbial resilience to drought after rewetting cycles in a variety of environments (Nijs et al., 2019; Zhou et al., 2019) in which increased species richness contributes to functional redundancy with implications for carbon storage (Allison \& Martiny, 2008).

The goal of this study was to 1) determine the role of soil type, elevation, and early snowmelt on biogeochemical processes during litter decomposition, 2) evaluate the effects of litter presence, type, and seasonal shifts in soil moisture on microbial decomposition processes, and 3) understand the resilience of soil microbial ecology to low moisture conditions. Within our study domain, we hypothesized that soil respiration rates and microbial community richness would be greatest during summer rewetting events. In addition to these biogeochemical indicators, needle decomposition and organic carbon export would be most pronounced at the mid-elevation where

PeerJ reviewing PDF | (2021:03:59500:2:0:NEW 9 Jul 2021) 
92 moisture and temperature were less limiting. By extension, we expected enhanced needle

93 decomposition and organic carbon export at the mid-elevation with early snowmelt further

94 enhancing decomposition and microbial respiration rates.

95

96

97

98

99

100

101

102

103

104

105

106

107

108

109

110

111

112

113

114

115

116

117

118

119

120

121

122

123

124

125

126

127

128

129

130

131

To address these research questions, we isolated lodgepole and spruce needles from the hydrobiogeochemical complexity of the forest. Harvested needles were deployed in similar slope and aspect open meadows representative of three ecoregions within Colorado. This allowed insight into the specific roles of tree litter on local soil biogeochemistry. Measurements including gas flux, porewater chemistry, microbial community structure, and changes in needle mass and chemistry were monitored over three years (2017-2019) and across three elevations ranging from 2,800-3,500 meters. Snowmelt was accelerated annually at the middle elevation adjacent to a control plot that underwent natural snowmelt rates to enable further investigation of snowmelt timing. The experiments encompassed large differences in snowpack and precipitation during a historically warm period, further enriching the observed impacts of climate change on local biogeochemical cycling (Colorado State Forest Service, 2020).

\section{Materials \& Methods}

\section{Needle collection and deployment}

Conifer needles were collected from regions of Colorado identified in our prior work and transported to established field plots (Brouillard et al., 2017; Leonard et al., 2020a). This enabled us to study isolated decomposition processes in response to climate-associated variables in the field. Lodgepole pine (Pinus contorta) needle litter was harvested from the White River National Forest $\left(39.54^{\circ} \mathrm{N}, 106.15^{\circ} \mathrm{W}\right.$, elevation 3,000 meters) while Engelmann spruce (Picea engelmannii) needles were harvested from Monarch Pass $\left(38.50^{\circ} \mathrm{N}, 106.33^{\circ} \mathrm{W}\right.$, elevation 3,400 meters). The needles were harvested beneath respective tree stands in August of 2016 and airdried at room temperature in a dark location. The dried needles were sieved with a Tyler Equivalent 10 mesh $(1.7 \mathrm{~mm})$ to separate debris and homogenize samples. Aliquots of 250 grams for each needle type were weighed and separated for deployment in October 2016.

Experimental plots were established at three elevations. An additional plot at the middle elevation was subjected to accelerated snowmelt for a total of four distinct plots. In order to focus on litter decomposition with minimal interference from flora, native foliage was raked to remove aboveground plant matter and belowground roots within the footprint of deployed $25 \mathrm{~cm}$ diameter and $18 \mathrm{~cm}$ height polyvinyl chloride (PVC) rings. The rings were pounded into the ground leaving approximately $10 \mathrm{~cm}$ of the ring aboveground. Lysimeters (Soil Moisture 1905L06 15cm) were installed in the middle of each ring for future porewater collections (Figure 1A). A total of 48 rings were deployed across the three elevations with a duplicate plot at the middle elevation consisting of four replicates of the spruce, lodgepole, and needle-free controls as depicted in Figure 1B. The controls were bare soil within the rings while the spruce and lodgepole rings were filled with 250 grams of the respective needles. Randomization was

PeerJ reviewing PDF | (2021:03:59500:2:0:NEW 9 Jul 2021) 
132 ensured using R Studio version 3.5.2 to produce $4 \times 4$ matrices with sample assignments as 133 depicted in Figure 1B. The experimental plots were monitored during the snow-free months of 134 May through October during the years 2017, 2018, and 2019. In October of 2017, one of each 135 sample quadruplicate was sacrificed to inform additional studies published in Leonard et al., 136 2020a. This reduced sample replicates to three thereafter. The needle deployments limited native 137 plant growth within the rings, however any observed emergent plant growth within the sample 138 rings was manually pulled including the roots monthly to minimize native foliage interferences. 139 Temporal soil biogeochemical analyses including soil extractions, gas flux, porewater, and microbial DNA were conducted with sampling frequency and totals dependent on each method and media type sampled (Figure 2).

142

143

In August of 2017, needle litter bags were deployed at each elevation to more effectively quantify mass loss associated with decomposition. The needle bags were constructed by wrapping 2 grams each of archived lodgepole and spruce needles in a single layer of white nylon mesh fabric $(23 \times 23$ openings per $2.54 \mathrm{~cm})$ that was further wrapped in one layer of window screen $(17 \times 13$ openings per $2.54 \mathrm{~cm})$. This contained the needles in a $5 \times 5 \mathrm{~cm}$ flat surface area. Quadruplicates of the litter bags were placed level to the ground inside newly emplaced PVC rings. The PVC rings were deployed according to the same methods as the sample rings by removing native foliage and maintaining bare soil. Mass balance from each elevation after three years of needle decomposition (August 2017-August 2020) was calculated by the differences in weight from the initial 2 grams and the final 2020 needles in each litter bag.

153

\section{Experimental plot descriptions}

155

156

The experimental field plots were located in Crested Butte, Colorado within the Washington Gulch drainage of the East River watershed in designated areas approved by the Rocky Mountain Biological Laboratory. Field plots were established at three ecoregions: Lower Montane $\left(38.92^{\circ}\right.$ $\mathrm{N}, 106.95^{\circ} \mathrm{W}$, elevation 2,800 meters), Lower Subalpine $\left(38.96^{\circ} \mathrm{N}, 107.03^{\circ} \mathrm{W}\right.$, elevation 3,100 meters), and Upper Subalpine ( $38.97^{\circ} \mathrm{N}, 107.04^{\circ} \mathrm{W}, 3,500$ meters) (Figure 1B). These ecoregions are within the identified boreal wet forest and polar wet tundra Holdridge life zones (GeoNetwork, 2007). The study plots were established within northeast/ east facing aspect meadows with an average slope of $7-12^{\circ}$ and will be referred to as the "Lower", "Middle", and "Upper" plots throughout the paper. The soil types of each location were unique with Tilton sandy loam at the Lower plot, a mixture of Tilton sandy loam, Cryaquolls and Histosols at the Middle, and Bucklon silt loam at the Upper plot (United States Department of Agriculture, 2019). The dominant bedrock material of Crested Butte in the study location is Sedimentary Clastic Mancos Shale with a mixture of Middle Tertiary Intrusive Igneous (U.S. Geological Survey, 2005).

169

Snowmelt timing increased with elevation and the earliest snow-free dates occurred at the Lower 171 plot (Table S1). Duplicate plots at the Middle elevation were established to further contrast the 
172 effects of snowmelt timing (Figure 1B). Early snowmelt manipulations were implemented once 173 isometric snowpack conditions were established in the middle of April (April 10-25) from 2017-

174 2019. During deployment, a permeable 50\% black mesh fabric was carefully secured on top of 175 the snow over the duplicate Middle plot for approximately one month as described in Leonard et 176 al., 2020b. The tarp was removed shortly after the plot had fully melted and while snowpack 177 within the control plot remained. These two Middle plots will be referred throughout the paper as the "Middle-ES" for the early snowmelt plot and "Middle" for the control snowmelt plot.

184

185

186

187

188

189

190

191

192

193

194

195

196

197

198

199

200

201

202

203

204

205

206

207

208

209

210

A snow telemetry (SNOTEL) station near the study locations on Mt. Crested Butte $\left(38.89^{\circ} \mathrm{N}\right.$, $106.95^{\circ} \mathrm{W}$, elevation $3,100 \mathrm{~m}$ ) provided climate records for local weather data (Figure $\mathrm{S} 1$ ). SNOTEL data for daily maximum air temperature, maximum soil moisture percentages at $20 \mathrm{~cm}$ depth, and snow water equivalent (SWE) precipitation were tabulated for each study water year and averaged to determine climate normals for comparison. Water years were determined by the twelve months starting on October $1^{\text {st }}$ and ending on September $30^{\text {th }}$ of the following year. Averaged 20-year normals were calculated from 1990-2010 for all climate variables except soil moisture, which only had reliable data sufficient for a ten-year average from 2006-2016. In addition to SNOTEL data, unshielded microclimate sensors buried at roughly $12 \mathrm{~cm}$ were established at each of the four experimental plots to monitor hourly soil moisture and temperature that were used to determine daily average values. Microclimate measurements were recorded from 2017- 2019 at the Lower and Middle plots and 2017-2018 at the Upper plot (Figure S2).

\section{Needle, soil, and porewater compositional analyses}

A chemical analysis of the 2016 harvested and 2019 decomposed needles focused on temporal shifts in carbon, nitrogen, and organic functional groups. These analyses were conducted with small subsamples collected over a three-year window of less than $5 \%$ of the total needles. The collected needles were air-dried, homogenized, and ground to a powder (Leonard et al., 2020a). Samples were submitted for total C and N measurements using a LECO TruSpec CN analyzer (LECO Corporation). A subset was submitted for Fourier Transform Infrared (FTIR) analysis at Lawrence Berkeley National Laboratory. Per the methods of Leonard et al., 2020a, the FTIR absorption spectra were baseline corrected in R Studio version 3.5.2 using R package hyperSpec (Beleites \& Valter, 2018) and peak-by-peak integration analysis was conducted to quantify organic functional groups of interest. Specifically, biological-related functional groups (Naumann, 2000) observed in litter and bark studies (Pandey \& Pitman, 2003; Özgenç, Durmaz \& Kuştaş, 2017; Yang et al., 2019) were targeted for sample comparisons. The prominent peaks identified within this study were polysaccharides $\left(900-1200 \mathrm{~cm}^{-1}\right)$, cellulose-based ether linkages (1157-1159 $\left.\mathrm{cm}^{-1}\right)$, lignin-based aromatics (1508-1510 $\left.\mathrm{cm}^{-1}\right)$, amide I $\left(1600-1700 \mathrm{~cm}^{-1}\right)$, and carbonyl typically at $1738 \mathrm{~cm}^{-1}$.

Peerj reviewing PDF | (2021:03:59500:2:0:NEW 9 Jul 2021) 
211 Soil extractions were conducted in 2020 in association with plot deconstruction. Soil was

212 collected from the upper 2-3 cm soil horizon in contact with needle decomposition, homogenized

213 on-site, and frozen at $-20^{\circ} \mathrm{C}$ until analysis. Deionized (DI) water extractions of soils followed the

214 methods from Leonard et al., 2020a. In brief, samples were sieved at $2 \mathrm{~mm}$ and a 2:9 solid mass

215 to liquid weight ratio using $40 \mathrm{~mL}$ liquid volume for extraction in $50 \mathrm{~mL}$ centrifuge tubes. The

216 tubes were placed on a shake plate for one hour, then centrifuged and filtered at $0.45 \mu \mathrm{m}$.

217 Aliquots of the filtrate were acidified with hydrochloric acid and analyzed for total nitrogen (TN)

218 and dissolved organic carbon (DOC) using a Shimadzu TOC-550A Total Organic Carbon

219 Analyzer. The remaining filtrate was analyzed by ion chromatography for nitrate and nitrite, by

220 colorimetric assays for ammonia, and by specific UV absorbance (SUVA) with a DU 800

221

222

223 Spectrophotometer. Extraction results were normalized to dried soil weights.

Porewater yields were sufficient during the shoulder months of spring and fall. All porewater collections were conducted on the same date when full snowmelt was established at each plot.

225 Soil porewater was collected from the lysimeters in each sample ring over 12 hours with 50mL Soil Moisture locking vacuum syringes to ensure sufficient water yields. The syringes were

227

228

229

230

231

232

233

234

235

236

237

238

239

240

241

242

243

244

245

246

247

248

249 covered in canvas cloth to prevent sample interference from solar radiation. The porewater samples were filtered at $0.45 \mu \mathrm{m}$ and frozen the same day of collection for storage at $-20{ }^{\circ} \mathrm{C}$ until analysis. The porewater was analyzed for TN, DOC, and SUVA following the same methods for the filtrate from the soil DI water extractions. Porewater sampling was not possible at the Lower plot in 2018 due to dry conditions.

\section{Soil gas flux}

Gas flux measurements were conducted in 2017-2019 at the Middle plots (14 sampling events) and during 2017-2018 at the Lower plot (9 sampling events) (Figure 2). Equipment access was not feasible at the Upper plot. Gas flux measurements were conducted using a Picarro G2508 cavity ring-down spectroscopy analyzer capable of measuring $\mathrm{CO}_{2}, \mathrm{CH}_{4}, \mathrm{~N}_{2} \mathrm{O}$, and $\mathrm{NH}_{3}$. A closed system was established within the headspace of each sample ring by placing an airtight PVC chamber over the deployed rings. Norprene tubing was used to circulate cavity headspace from the PVC chamber to the analyzer inlet and outlets. Flux data collection typically occurred midday. Sample collection would begin when steady state was determined by linear trends of production or removal, initiating a two-minute data collection period for each sample. Fluxes were calculated using the Hutchingson \& Mosier method provided in the Picarro software using the calculated headspace volume. The sampling sequence was randomized during each measuring event to minimize temporal biases associated with hourly fluctuations in temperature. Further, the two plots at the Middle elevation were measured simultaneously during measurements, alternating between the Middle and Middle-ES plots for each sample.

\section{Soil microbial DNA extraction \& rRNA gene sequencing}

PeerJ reviewing PDF | (2021:03:59500:2:0:NEW 9 Jul 2021) 
250 Soil for DNA extractions was collected from surficial soils ( $<2-3 \mathrm{~cm}$ depth) after gently pushing

251

252

253

254

255

256

257

258

259

260

261

262

263

264

265

266

267

268

269

270

271

272

273

274

275

276

277

278

279

280

281

282

283

284

285

286

287

288

289 aside existing needles. Within the area of the sample ring, no less than 10 grab samples were collected with autoclaved spatulas to fill a $2 \mathrm{~mL}$ sample collection tube up to $1 \mathrm{~g}$ for each sample ring. The grab samples were randomized throughout the ring's surface area to minimize biases. DNA extraction and amplification were conducted for each sample in singlet following the methods of Leonard et al., 2020a. In brief, soil DNA was extracted using the ZymoBIOMICS DNA Miniprep kit and 0.25 grams of soil were weighed out from the $2 \mathrm{~mL}$ sample collection tube after homogenizing the total sample mass. The 5 PRIME Hot MasterMix and a primer set using the 515-Y forward and 926R reverse primers were used to amplify the $16 \mathrm{~S}$ and $18 \mathrm{~S}$ ribosomal RNA genes (Parada, Needham \& Fuhrman, 2016). Sample barcoding with the amplicons was completed using an adapted forward primer with the M13 sequence (Caporaso et al., 2012; Stamps et al., 2016). Final DNA concentrations were determined using the Qubit 2.0 fluorometer. Libraries were sequenced at the Duke Center for Genomic and Computational Biology using an Illumina MiSeq instrument and V2 PE250 chemistry. The raw sequencing reads were processed as described in Leonard et al., 2020a using the DADA2 package (Callahan et al., 2016) and taxonomic assignments with Silva v128 (Pruesse, Peplies \& Glöckner, 2012). After quality filtering the $16 \mathrm{~S}$ genes a total of 2,500,000 sequences were obtained with a sequence depth range of $9765 \pm 4270$. Normalization was performed by rarefaction at 4,299 which retained 224 out of 254 samples. Similarly, 102,000 sequences were obtained after filtering the $18 \mathrm{~S}$ genes with a sequence depth of $400 \pm 420$. Due to the high variance in depth, rarefaction was performed at 200, retaining 143 out of 254 samples. Raw sequence data have been deposited in NCBI SRA databases under access number PRJNA 605259 for the Middle site 2017-2018 samples previously published in Leonard et al., 2020a and PRJNA 715914 with the rest of the samples. Rarified samples were further processed in R Studio version 3.5.2 using the Phyloseq (v1.26.1) R package for data sorting, analysis, and visualization (McMurdie \& Holmes, 2013 ) in addition to statistical analyses and visualization packages described in the next section.

\section{Statistical analyses}

Due to low sample sizes $(n=3)$, Friedman and post hoc Wilcoxon tests were not used in this study for statistical determinations. As a result, mean and associated standard deviation values for environmental triplicates were used as alternatives when appropriate for geochemical parameters including needle composition, porewater, soil extractions, and gas flux. Possible significance between samples was indicated by non-overlapping error bars. Gas flux data were binned by year to assess linear Pearson correlations between annual flux and soil parameters.

DNA sequencing data were analyzed for beta and alpha diversity. Beta diversity of samples binned by elevation (Lower, Middle, and Upper) was determined using the Adonis function as an analogous multivariate analysis of variance using weighted and unweighted UniFrac distance matrices in the community ecology R package vegan (Oksanen et al., 2019). The Adonis test was followed by principal coordinate analyses ( $\mathrm{PCoA}$ ) performed on the weighted and unweighted

Peer] reviewing PDF | (2021:03:59500:2:0:NEW 9 Jul 2021) 
290

291

292

293

294

295

296

297

298

299

300

301

302

303

304

305

306

307

308

309

310

311

\section{Variation of season, elevation, and accelerated snowmelt}

313 The three-year study encompassed a wide range of weather patterns that impacted local soil

314

315

316

317

318

319

320

321

322

323

324

325

326

327

328

UniFrac distances. In addition, the dual Middle plots (Middle and Middle-ES) were compared separately from the full dataset to determine if significant differences were present as a function of snowmelt. Next, the same methods of the Adonis function followed by PCoA were conducted across all samples as a function of sample date for each elevation to determine temporal differences in beta diversity. Alpha diversity richness was determined for each sample by calculating observed mean richness and standard deviations with sample replicates followed by visual plots of the results as a time series for each sample date (Berry, 2016).

Further, canonical correspondence analysis (CCA) was conducted using the weighted UniFrac distance matrices in statistical software Past 4.01 (Hammer et al., 2001). Environmental conditions of daily average soil moisture and soil temperature from the microclimate sensors at each plot and monthly total precipitation data from the SNOTEL database were included in the CCA to understand the influences of soil conditions on community clustering. Due to a lack of microclimate data at the Upper plot, a CCA was not generated for this location. Finally, mean relative abundances were determined by phylum and family bacterial assignments with the 15 most abundant taxa ranked for binned samples (control, spruce, and lodgepole) across date and location using the ampvis2 package (Andersen et al., 2018). Differences in mean relative abundances across sampling dates were visually observed, but also statistically confirmed using differential abundance comparisons in R package DESeq2 (Love, Huber \& Anders, 2014). A $P$ value less than 0.05 was considered significant in all statistical tests.

\section{Results} temperature and moisture (Figure 2). Based on the SNOTEL database and microclimate sensor data from each plot, an active monsoon in the summer of 2017 was followed by a dry year with below-average snow water equivalent (SWE) precipitation in 2018 (Table 1). In 2019, SWE rebounded to almost double the prior year. Precipitation averaged $77 \pm 25 \mathrm{~cm}$ (SWE) over the study period with a higher snow fraction that ranged from $60-70 \%$ of total precipitation. SNOTEL soil moisture data were consistent with these trends with above-average dry soil days in 2018 .

In addition to climate variability observed in 2017-2019, early snowmelt deployments allowed us to experimentally manipulate the variable of snowmelt timing. Over the three study years, the permeable tarp deployment at the Middle-ES plot accelerated snowmelt by $15 \pm 7$ days in contrast to the control Middle plot. This was evidenced by the microclimate soil temperature profiles and visual time-lapse capture of plant growth (Figure S2). Early snowmelt advanced spring plant greening by as much as 22 days in 2017 and both snowmelt and plant growth timing visually mimicked that of the Lower plot (-300 meters). The Middle-ES snowmelt plot became 
329

330

331

332

333

334

335

336

337

338

339

340

341

342

343

344

345

346

347

348

349

350

351

352

353

354

355

356

357

358

359

360

361

362

363

364

365

366

367

368

indistinguishable from the parallel Middle plot in visual appearance as well as soil moisture and temperature values as the summer progressed.

\section{Needle decomposition}

Spruce and lodgepole needle compositional changes were determined by comparing initial harvested needle carbon and nitrogen totals to the decomposed 2019 samples across experimental variables of elevation and snowmelt. While triplicate deployments limited statistical confirmation, no clear differences in average litter bag mass losses were observed as a function of elevation or snowmelt due to overlapping standard deviations of decomposed samples (Table S2). When needle litter bag mass losses were binned across elevation (Lower, Middle, Upper), this returned a total mass loss after three years of $21 \pm 4 \%$ for lodgepole and 16 $\pm 3 \%$ for spruce (Table S2). In agreement with mass loss, no pronounced differences in average $\mathrm{C}: \mathrm{N}$ ratios for lodgepole needles were observed across elevation after decomposition (Figure 3). This was similarly observed in the spruce needles between the Lower and Upper plots, but interestingly the Middle plot spruce ratio was comparatively lower. No pronounced differences in average $\mathrm{C}: \mathrm{N}$ ratios were observed across snowmelt manipulations. Overall there was a temporal decrease in C:N ratios of approximately $32 \pm 4 \%$ in spruce and $22 \pm 3 \%$ in lodgepole after three years of decomposition (Figure 3). As a result, total carbon decreased in the lodgepole needles by approximately $9 \pm 3 \%$ and $3 \pm 10 \%$ for spruce, but with a large variance in spruce from an increase in total carbon at the Upper plot. Total nitrogen increased in both spruce and lodgepole needles by $44 \pm 13 \%$ and $17 \pm 7 \%$, respectively (Table S3).

Needle organic composition was analyzed to further understand decomposition processes. The FTIR spectra for the needle samples after three years of decomposition were similar across elevation and snowmelt manipulations (Figure S3). Peak integrations were conducted for select organic groups to explore shifts in organic composition over time (Table S4). This revealed a decreased presence of polysaccharides and increased relative presence of amides and aromatics after three years of decomposition. Lodgepole needles contained more labile ether linkages in contrast to a higher presence of recalcitrant lignin-type aromatics in the spruce needles throughout the three years. The ratio of the polysaccharide to amide I peaks served as an estimate of organic C:N ratios. Consistent with total C:N values (Figure 3), no differences were found across elevation for spruce and lodgepole litter; however, a temporal decrease in this ratio was observed for both sample types (Table S4).

\section{Porewater \& soil extractions}

Soil porewater samples were collected to quantify dissolved organic carbon (DOC) and total dissolved nitrogen (TN) concentrations across elevations and study years. Differences in average values were observed across elevation based on standard deviation values with consistently higher concentrations of control sample porewater DOC and TN at the Lower plot $(15.1 \pm 1.7$ $\mathrm{mg} / \mathrm{L} \mathrm{DOC}, 2.3 \pm 1.2 \mathrm{mg} / \mathrm{L} \mathrm{TN})$ in contrast to the Middle $(7.2 \pm 3.4 \mathrm{mg} / \mathrm{L} \mathrm{DOC}, 0.4 \pm 0.3 \mathrm{mg} / \mathrm{L}$

Peer] reviewing PDF | (2021:03:59500:2:0:NEW 9 Jul 2021) 
$369 \mathrm{TN})$ and Upper $(2.8 \pm 1.1 \mathrm{mg} / \mathrm{L}$ DOC, $0.3 \pm 0.1 \mathrm{mg} / \mathrm{L} \mathrm{TN})$ (Figure 4). As a result, concentrations 370 of DOC and TN decreased with rising elevation. No consistent trends were determined as a 371 function of needle presence or type at each study plot. However, there was a suggestive trend 372 with respect to accelerated snowmelt where the Middle-ES plot exhibited higher DOC 373 concentrations than the Middle control plot. This trend was observed across samples with the 374 largest average increases observed under lodgepole needles in the spring sampling events (Figure 375 5). While the plots were adjacent but separate, variables beyond snowmelt timing cannot be fully 376 ruled out as a possible explanation. The porewater $\mathrm{TN}$ concentrations followed a similar trend 377 but standard deviation values overlapped (Figure S4).

378

379

380

381

382

383

384

385

386

387

388

389

390

391

392

393

394

395

396

397

398

399

400

401

402

403

404

405

406

407

408

Analogous to porewater results, sacrificial soil extractions at the end of the experiment exhibited differences across elevation with the highest DOC and TN concentrations at the Lower site. Control soil extractable concentrations were approximately five times higher at the Lower plot when contrasted with the Middle and Upper plots (Table 2). The higher TN concentrations at the Lower site were associated with greater levels of extractable nitrate in contrast to the other plots. Dissolved total organic nitrogen (TON) and nitrate constituted $>90 \%$ of the nitrogen species within the soil. Accelerated snowmelt did not appear to impact average soil DOC and TN between the Middle and Middle-ES plots (Table 2). In contrast to porewater, the presence of needles resulted in higher extractable soil DOC across elevations when compared to the needlefree control rings (Table 2). Higher extractable DOC was associated with lodgepole needles relative to spruce.

\section{Gas flux}

To further understand the influence of needle decomposition in conjunction with climate variables on terrestrial carbon cycling, gaseous carbon flux was measured at both the Lower and Middle plots. Gas flux did not differ between the Lower and Middle plots or as a function of snowmelt manipulation based on overlapping standard deviation values (Figure 6). Peaks in average $\mathrm{CO}_{2}$ production were observed across elevation in association with moisture events which returned flux values 2-3 times higher than rates during low moisture periods (Figures 2, 4, and 6). The seasonal $\mathrm{CO}_{2}$ flux was further heightened by the presence and type of needle litter (Figures 6 and S5). This held true when contrasting the comparatively wet summer of 2017 with drier years in 2018 and 2019 (Figures 6 and S6). Pearson correlations returned inconsistent correlations between total annual flux measurements and soil moisture and temperature (Table S5). Observed average $\mathrm{CH}_{4}$ fluxes were not appreciably different as a function of elevation, snowmelt manipulation, needle presence, or type (Figure S7). Average control $\mathrm{CH}_{4}$ consumption was $-0.7 \pm 0.1 \mathrm{mg} \mathrm{C} \mathrm{m}^{-2} \mathrm{~d}^{-1}$ for the Lower plot and $-1.0 \pm 0.5 \mathrm{mg} \mathrm{C} \mathrm{m}^{-2} \mathrm{~d}^{-1}$ at the Middle plot in 2017-2018 (Figure 4). Additionally, $\mathrm{NH}_{3}$ and $\mathrm{N}_{2} \mathrm{O}$ fluxes exhibited high variability and no clear trends of production or removal.

\section{Microbial ecological responses}

PeerJ reviewing PDF | (2021:03:59500:2:0:NEW 9 Jul 2021) 
409 Microbial community clustering was significant across locations as indicated by the Adonis 410 multivariate analysis of variance using weighted and unweighted UniFrac distance matrices 411 (Figure S8). These differences were observed across elevation for both 16S bacterial and 18S 412 eukaryotic genes $(P<0.05)$. Further comparisons between the two Middle plots revealed that 413 accelerated snowmelt did not significantly impact community clustering. Needle presence and 414 type however influenced community clustering across elevations with a reliance on both date and 415 location. Specifically, when Adonis analyses were conducted for each sample type across each 416 year, significant differences in community beta diversity were observed in 2018 at the Lower and 417 Middle plots. Due to low sample counts, this was not observed at the Upper plot (Table S6).

418

419 The alpha diversity time series (Figure 7) further highlighted the impact of seasonal shifts on 420 bacterial community structure and diversity in 2018 at the Lower and Middle plots with a 421 relative increase in species richness in July 2018 for all sample types. Analogous trends were 422 observed in the alpha diversity time series at the Upper plots (Figure S9), but there was high 423 variance in standard deviations. Mean relative familial abundance analyses further detailed 424 community shifts in specific taxa at the Lower and Middle plots by contrasting early-season May 4252018 against a drier July and October 2018 (Figure S10). Upon visual inspection of the heatmaps and statistical confirmation using differential abundance analysis, clear changes occurred in 2018 for specific taxa. As a result, relative abundances of the early-season taxa of primarily

429

430

431

432

433

434

435

436

437

438

439

440

441

442

443

444

445

446

447

448 Chitinophagaceae, among others fell in July or October of 2018 at each elevation with fewer dominant families not observed previously increased in relative abundance. This corresponded to an average increase in community richness that was most pronounced at the Middle elevation (Figure 7) in 2018 as well as significant differences in variance in 2018 at both the Lower and Middle elevations (Table S6). In contrast to the bacterial communities, this trend was less clear in eukaryotic 18S richness (Figure S9 and S11). Visually, shifts in relative abundances of specific phyla were observed (Figure S12); however, due to low sample counts during rarefaction, the changes were not statistically confirmed with differential abundance comparisons. Few consistent trends in specific bacteria were found at the genus level except for drought-resistant Mycobacterium and Isosphaera which were present in multiple samples at the Middle and Lower plots during the dry phase in July 2018. The observed trends at the Upper plot were less clear due to high variance; however, it is recognized that fewer total samples were collected at this location with incomplete soil moisture and temperature data (Figures S9 and $\mathrm{S} 11)$.

The CCA plots highlighted the association of precipitation, soil moisture, and soil temperature with the observed shifts in bacterial community structure in 2018 (Figure 8). Specifically, at the Lower plot, the 2018 samples clustered by date with May and July 2018 samples associated with lower precipitation (32 $\pm 5 \mathrm{~mm})$ and soil moisture $(14 \pm 3 \%$ ) whereas October 2018 clustered in association with higher precipitation $(58 \pm 22 \mathrm{~mm})$ and soil moisture $(22 \pm 1 \%)$. Interestingly, the September 2019 microbial samples also clustered in proximity with high soil moisture and 
449 sampling dates, despite low precipitation $(6 \mathrm{~mm})$ and moisture (10\%) conditions. The July 2018 450 samples at the Middle plot clustered tightly in association with lower precipitation (37 $\mathrm{mm})$ and 451 soil moisture (11\%). The Middle-ES plot returned similar associations with the 2018 samples 452 clustered separately from the 2017 and 2019 samples. Due to low sample counts after 453 rarefaction, the 18S CCA plots returned high variability, which limits interpretation (Figure 454 S13).

\section{Discussion}

456

457

458

459

460

461

462

463

464

465

466

467

468

469

470

471

472

473

474

475

476

477

478

479

480

481

482

483

484

485

486

487

488

This three-year experiment was designed to monitor needle decomposition and associated biogeochemical responses across the climate variables of elevation, snowmelt, and season in simplified soil plots. Our subsequent monitoring window encompassed a wide range of annual variability in snowpack and precipitation that included abnormally dry conditions. As such our results provide insight into carbon, nitrogen, and microbial shifts in montane and subalpine ecoregions during dry soil conditions and early snowmelt that are projected to become more frequent under climate change (Lukas et al., 2014). Additionally, by contrasting lodgepole and spruce litter against bare soil, we were able to discern contributions from conifer needle litter to biogeochemical processes.

\section{The roles of soil type, elevation, and accelerated snowmelt on soil biogeochemistry}

The experimental 700-meter elevation gradient across montane and subalpine ecoregions harbored clear differences in the baseline soil properties of porewater, extractable organic carbon and nitrogen, and microbial community structure (Figure 4). While soil characteristics drive bioavailable carbon, nitrogen (Delgado-Baquerizo et al., 2015), resident microbial communities (Thomson et al., 2015), and soil moisture (Lawrence \& Hornberger, 2007), trends as a function of elevation are not consistent. Past studies across a 1,000-meter gradient determined inconsistent trends in soil organic carbon across elevation (Djukic et al., 2010), while a larger gradient of 3,000 meters established positive and negative correlations in soil carbon and nitrogen content with altitude and temperature, respectively (Tashi et al., 2016). In our present study, the elevation gradient of 300 meters between the Lower and Middle plots did not appreciably impact gas flux (Figure 6), while mass losses from deployed conifer needles were similar across the full 700-meter gradient (Table S2). This was surprising considering the differences in snowmelt timing across elevation (Table S1); however, these results agree with other studies that have shown minimal impact on microbial structure with no lasting effects on microbial biomass and nutrient cycling processes after experimental snowmelt manipulations (Conner, Gill \& Harvey, 2017; Darrouzet-Nardi et al., 2019). A plausible explanation is that ecological resilience overcomes the effects of accelerated snowmelt without additional climate variables of higher temperatures and lower precipitation (Darrouzet-Nardi et al., 2019).

Snowmelt timing has been shown to influence litter decomposition rates associated with freezethaw cycles by releasing more nutrients to bacteria that become active during thawing (Zhu, Yang \& He, 2013). While the decomposition rates over three years of our study were not

Peerj reviewing PDF | (2021:03:59500:2:0:NEW 9 Jul 2021) 
489

490

491

492

493

494

495

496

497

498

499

500

501

502

503

504

505

506

507

508

509

510

511

512

513

514

515

516

517

518

519

520

521

522

523

524

525

526

527

528

considerably different between the Middle plots, soil porewater DOC consistently trended higher under accelerated snowmelt in the spring. These trends continued in the fall, but with higher variability in significance (Figure 5). While the Middle-ES plot could have locational bias, the two plots (Middle and Middle-ES) were in proximity, of the same soil type, and the greatest differences were observed only under the lodgepole needles. Carbon losses can be enhanced with spring timing, early-season frost events, and late-season drought (Arnold, Ghezzehei \& Berhe, 2014), all of which are location-dependent. Collectively, these observations could be explained by a climate-related phenomenon associated with more labile litter decomposition. Conifer litter decomposition depends on the quality, or bioavailability of organic matter and nutrients, resulting in different biogeochemical responses as a function of tree needle type (Leonard et al., 2020a). As a result, lower quality needles can limit bioavailable organics, while soil type is more influential in potential decomposer limitations under higher quality litter (Vesterdal, 1999).

Collectively, this suggests that accelerated snowmelt could increase access to nutrients under high quality litter during the spring thaw cycle for microbes becoming more active under early snowmelt. Interestingly, this is in contrast to the findings of Conner, Gill \& Harvey, 2017 in which no changes were observed in soil DOC over three years of early snowmelt in a subalpine aspen forest. These conflicting results reveal the limitations in this study from the exclusion of native foliage, as the observed effects of early snowmelt on carbon cycling can be mediated by plant growth (Wipf, Rixen \& Mulder, 2006; Conner, Gill \& Harvey, 2017).

\section{The importance of needle litter and seasonality}

While differences in soil temperature and moisture across a 700-meter gradient exerted little influence, needle presence and type increased soil DOC and $\mathrm{CO}_{2}$ fluxes across the elevation transect. Despite overlapping in significance, there was a trend toward higher mass losses and higher rates of heterotrophic respiration in association with lodgepole needles across elevations (Figure 6). This agrees with other studies at lower forest elevations (Fujii et al., 2018), subarctic tundra (Sundqvist, Giesler \& Wardle, 2011), and a subalpine elevation gradient (Zhu, Yang \& He, 2013) that collectively concluded that plant litter type affects decomposition rates more than abiotic influences found across climate regimes. In support of higher mass loss rates, needle decomposition also influenced heterotrophic respiration with as much as twice the $\mathrm{CO}_{2}$ production under lodgepole samples in contrast to needle-free controls. This is consistent with earlier findings confined to the Middle plot (Leonard et al., 2020a) where lodgepole needles provided a more labile carbon source than spruce. Further, as expected from previous findings, peaks in $\mathrm{CO}_{2}$ production were associated with wetter soils from snowmelt and precipitation events (Figure 6) while $\mathrm{CH}_{4}$ consumption remained relatively consistent. This supports prior findings where $\mathrm{CO}_{2}$ production is more dependent on climate whereas $\mathrm{CH}_{4}$ consumption relies more strongly on soil characteristics (Gulledge \& Schimel, 2000).

Heterotrophic respiration depends on both water availability (Liu, Zhang \& Wan, 2009) and temperature (Schindlbacher et al., 2011). As a result, both variables likely influence respiration 
529 rates as driven by soil saturation thresholds. This was observed in a prior boreal forest study 530 where $\mathrm{CO}_{2}$ production in dry soil conditions, defined as below soil half-saturation, was more 531 sensitive to moisture, while wetter conditions were more dependent on temperature (Gulledge \& 532 Schimel, 2000). This phenomenon could explain our observation of conflicting correlations 533 across plots. Alternatively, or in tandem, this could be explained by interchanges between abiotic 534 and microbial activity-related influences on $\mathrm{CO}_{2}$ rates where high moisture release is driven 535 more by microbial respiration and low moisture release by abiotic mechanisms. This is consistent 536 with the observed slowing of microbial activity during dry periods in previous studies (Davidson, 537 Belk \& Boone, 1998; Wu et al., 2011; Carbone et al., 2011). As brought to question by Schimel, 5382018 the mechanisms which increase $\mathrm{CO}_{2}$ during rewetting events are unclear. However, our 539 study suggests increased biotic mechanisms under needle decomposition by demonstrating that 540 areas with more labile litter are associated with higher carbon fluxes during moisture events. It 541 has been projected that seasonal shifts in soil moisture will increase overall soil respiration in 542 montane and subalpine ecoregions such as those analyzed here (Kramer \& Chadwick, 2018). In

543 our study, dry soil conditions were associated with low baseline fluxes and repressed

544 heterotrophic activity. This could become more frequent with projected increases in temperature 545 if precipitation remains the same or decreases. By extension, there could be decoupling from 546 temperature where moisture would be the main determinant of microbial activity and $\mathrm{CO}_{2}$ 547 respiration rates (Gulledge \& Schimel, 2000). While drought could repress carbon release, this 548 could be associated with more pronounced export during rewetting (Meisner et al., 2017).

549

\section{Microbial resilience and response to drought}

551 A temporal analysis of microbial community structure across deployments provided further

552

553

554

555

556

557

558

559

560

561

562

563

564

565

566

567

568 insights. Consistent with heterotrophic respiration rates, resident bacterial communities were influenced by needle presence, type, and seasonal shifts in soil moisture. This had previously been explored at the Middle plot in Leonard et al., 2020a. Our present study furthered insights across elevation with significant community variability depending on the sample date (Table S6). The CCA plots (Figure 8), and alpha diversity time series (Figure 7) emphasized the importance of reduced moisture and higher temperatures in bacterial ecology, which is supported by experimental simulations of drought (Rein et al., 2016) and a field study (Acosta-Martínez et al., 2014). Clear differences in bacterial communities were observed after the drier conditions of July 2018 as evidenced by significant beta diversity variance and increased alpha diversity species richness (Table S6, Figure 7). There are inconsistencies in the literature where drought has been documented to both increase and decrease overall microbial richness (Peñuelas et al., 2012; Ochoa-Hueso et al., 2018). Specifically, at the Middle and Lower plots, drought-resistant Mycobacterium of Actinobacteria (Torvinen et al., 2006) and Isosphaera of Planctomycetes (Dai et al., 2019) ranked as the top 15 most abundant taxa only in July 2018. Interestingly, during this period the bacterial family Chitinophagaceae experienced its most pronounced decrease. Analogous findings were observed for fungal communities where the relative abundance of Ascomycota Dothideomycetes and Basidiomycota Tremellomycetes increased in July 2018 and 
569 maintained higher abundances through 2019 at the Middle and Upper elevations under the needle 570 samples. This supports prior field drought-related findings of Acosta-Martínez et al., 2014.

571 More broadly, at the Phylum level, the July 2018 shift in community structure translated to a

572 decreased abundance of Bacteroides across elevation and samples; agreeing with observed

573 decreases in Bacteroides under elevated temperatures in other studies (Oliverio, Bradford \&

574 Fierer, 2017). Interestingly, this contrasts with a drought cycle study on agricultural land which

575 reported increased Bacteroides (Acosta-Martínez et al., 2014). That same study however

576 highlighted Acidobacteria as sensitive to temperature changes which was consistent with

577 observed increases in our system in 2018. These conflicting results highlight the importance of

578 soil type and location as well as limitations in interpreting and predicting taxonomic shifts

579 associated with a changing climate where heterogeneous mountain terrain is an example. Despite

580 the changes associated with July 2018, a return of the previously dominant pre-drought taxa and

581 abundances in 2019 provided evidence for microbial resilience across our elevation gradient.

582 This agrees with previous findings in which diverse communities are more resilient partially due

583 to rare taxa that can continue functional processes and increase in abundance in response to

584 disturbances (Shade et al., 2012). As a result, microbial communities have an inherent resilience

585 to disturbances (Allison \& Martiny, 2008) and greater tolerance than local flora and fauna

586 (Schimel, 2018). However, the dynamics of plant and microbial interactions, though not explored

587 in our current study, could impact these findings (de Vries et al., 2018).

588

\section{Conclusions}

590 This study highlights the sensitivity, but also the resilience of biogeochemical decomposition 591 processes to elevation, season, and snowmelt. An elevation gradient of $700 \mathrm{~m}$ or less will likely

592 have a minimal effect on the biogeochemical responses to drought conditions. Earlier snowmelt

593 in the timescale of weeks is not expected to significantly affect local biogeochemistry beyond an

594 increased potential for DOC release in organic horizons with more labile litter influences,

595 whereas climate plays a more prominent role in soil baseline conditions. While drier soil

596 conditions reduced heterotrophic respiration, carbon release could be magnified when moisture

597 rewetting returns. This is especially significant in high sensitivity biomes that include the studied

598 montane and subalpine ecoregions in Colorado. As a result, with higher dependency on moisture

599 events, increased carbon release in tighter timeframes could occur under litter decomposition.

600 The microbial communities are likely resilient to drought during short-term disturbances if soil

601 saturation returns, but the impacts of long-term drought need to be further understood. If

602 increased drought stress from climate change continues in Colorado, this could reinforce the

603 lower respiration rates and microbial community shifts observed in the 2018 dry season of this

604 study.

605

606 Acknowledgements

607 Field access and support were provided by the Rocky Mountain Biological Laboratory in Gothic,

608 CO with logistical support from Jennifer Reithel. We thank Kristin Mikkelson, Brent Brouillard, 
609 Chelsea Wilmer, Heidi Steltzer, Kayla Hubbard, Jake Wands, and Sabrina Nesladek for their 610 support of field activities. Zhao Hao conducted FTIR measurements and provided analysis 611 techniques. Comments from Gary Vanzin and Zackary Jones on a prior draft improved data 612 analysis and dissemination. Members of the Geo-Environmental Microbiology Laboratory at the 613 Colorado School of Mines provided ongoing support and friendship. We thank PeerJ editor Mark 614 Tibbett and two anonymous reviewers for their constructive suggestions during the peer review 615 process.

616

\section{References}

618 Acosta-Martínez V, Cotton J, Gardner T, Moore-Kucera J, Zak J, Wester D, Cox S. 2014. Predominant 619 bacterial and fungal assemblages in agricultural soils during a record drought/heat wave and 620

621 linkages to enzyme activities of biogeochemical cycling. Applied Soil Ecology 84:69-82. DOI:

622 10.1016/j.apsoil.2014.06.005.

623

Allison SD, Martiny JBH. 2008. Resistance, resilience, and redundancy in microbial communities.

624 Proceedings of the National Academy of Sciences 105:11512-11519. DOI:

625 10.1073/pnas.0801925105.

Andersen KS, Kirkegaard RH, Karst SM, Albertsen M. 2018. ampvis2: an R package to analyse and 626 visualise 16S rRNA amplicon data. bioRxiv:299537. DOI: 10.1101/299537.

627

628

629

630

631

632

633

634

635

636

637

638

639

640

641

642

643

Arnold C, Ghezzehei TA, Berhe AA. 2014. Early Spring, Severe Frost Events, and Drought Induce Rapid Carbon Loss in High Elevation Meadows. PLOS ONE 9:e106058. DOI: 10.1371/journal.pone.0106058.

Barnett TP, Adam JC, Lettenmaier DP. 2005. Potential impacts of a warming climate on water availability in snow-dominated regions. Nature 438:303-309. DOI: 10.1038/nature04141.

Beleites C, Valter S. 2018. hyperSpec: a package to handle hyperspectral data sets in $R$.

Berry M. 2016.Microbial Community Diversity Analysis Tutorial with Phyloseq. Available at http://deneflab.github.io/MicrobeMiseq/demos/mothur_2_phyloseq.html\#session_info (accessed March 16, 2021).

Birch HF. 1958. The effect of soil drying on humus decomposition and nitrogen availability. Plant and Soil 10:9-31. DOI: 10.1007/BF01343734.

Brouillard B, Mikkelson K, Bokman C, Berryman EM, Sharp J. 2017. Extent of localized tree mortality influences soil biogeochemical response in a beetle-infested coniferous forest. Soil Biology and Biochemistry 114:309318. DOI: 10.1016/j.soilbio.2017.06.016.

Callahan BJ, McMurdie PJ, Rosen MJ, Han AW, Johnson AJA, Holmes SP. 2016. DADA2: Highresolution sample inference from Illumina amplicon data. Nature Methods 13:581-583. DOI: 10.1038/nmeth.3869. 
644 Caporaso JG, Lauber CL, Walters WA, Berg-Lyons D, Huntley J, Fierer N, Owens SM, Betley J, Fraser 645 L, Bauer M, Gormley N, Gilbert JA, Smith G, Knight R. 2012. Ultra-high-throughput microbial

646

647

648

649

650

651

652

653

654

655

656

657

658

659

660

661

662

663

664

665

666

667

668

669

670

671

672

673

674

675

676 community analysis on the Illumina HiSeq and MiSeq platforms. The ISME Journal 6:16211624. DOI: $10.1038 /$ ismej.2012.8.

Carbone MS, Still CJ, Ambrose AR, Dawson TE, Williams AP, Boot CM, Schaeffer SM, Schimel JP. 2011. Seasonal and episodic moisture controls on plant and microbial contributions to soil respiration. Oecologia 167:265-278. DOI: 10.1007/s00442-011-1975-3.

Colorado State Forest Service. 2019 Report on the Health of Colorado's Forests. 2020. Colorado Department of Natural Resources, Colorado State University.

Conner LG, Gill RA, Harvey JT. 2017. Earlier snowmelt accompanied by warmer soil temperatures in mid-latitude aspen forest and subalpine meadow: Implications for soil carbon. Plant and Soil 417:275-285. DOI: 10.1007/s11104-017-3258-1.

Dai L, Zhang G, Yu Z, Ding H, Xu Y, Zhang Z. 2019. Effect of Drought Stress and Developmental Stages on Microbial Community Structure and Diversity in Peanut Rhizosphere Soil. International Journal of Molecular Sciences 20. DOI: 10.3390/ijms20092265.

Darrouzet-Nardi A, Steltzer H, Sullivan PF, Segal A, Koltz AM, Livensperger C, Schimel JP, Weintraub MN. 2019. Limited effects of early snowmelt on plants, decomposers, and soil nutrients in Arctic tundra soils. Ecology and Evolution 9:1820-1844. DOI: 10.1002/ece3.4870.

Davidson EA, Belk E, Boone RD. 1998. Soil water content and temperature as independent or confounded factors controlling soil respiration in a temperate mixed hardwood forest. Global Change Biology 4:217-227. DOI: 10.1046/j.1365-2486.1998.00128.x.

Delgado-Baquerizo M, García-Palacios P, Milla R, Gallardo A, Maestre FT. 2015. Soil characteristics determine soil carbon and nitrogen availability during leaf litter decomposition regardless of litter quality. Soil Biology and Biochemistry 81:134-142. DOI: 10.1016/j.soilbio.2014.11.009.

Djukic I, Zehetner F, Tatzber M, Gerzabek MH. 2010. Soil organic-matter stocks and characteristics along an Alpine elevation gradient. Journal of Plant Nutrition and Soil Science 173:30-38. DOI: https://doi.org/10.1002/jpln.200900027.

Fraterrigo JM, Ream K, Knoepp JD. 2018. Tree Mortality From Insect Infestation Enhances Carbon Stabilization in Southern Appalachian Forest Soils. Journal of Geophysical Research: Biogeosciences 123:2121-2134. DOI: 10.1029/2018JG004431.

Fujii S, Cornelissen JHC, Berg MP, Mori AS. 2018. Tree leaf and root traits mediate soil faunal contribution to litter decomposition across an elevational gradient. Functional Ecology 32:840 852. DOI: https://doi.org/10.1111/1365-2435.13027. 
677 GeoNetwork. 2007.GeoNetwork opensource portal to spatial data and information. Available at

678

679

680

681

682

683

684

685

686

687

688

689

690

691

692

693

694

695

696

697

698

699

700

701

702

703

704

705

706

707

708

709

710

711 http://www.fao.org/geonetwork/srv/en/main.home?uuid=c6f35470-88fd-11da-a88f000d939bc5d8 (accessed January 15, 2021).

Gulledge J, Schimel JP. 2000. Controls on Soil Carbon Dioxide and Methane Fluxes in a Variety of Taiga Forest Stands in Interior Alaska. Ecosystems 3:269-282. DOI: 10.1007/s100210000025.

Hyde K, Peckham S, Holmes T, Ewers B. 2016. Bark Beetle-Induced Forest Mortality in the North American Rocky Mountains. In: Biological and Environmental Hazards, Risks, and Disasters. Elsevier Inc.

Körner C. 2007. The use of 'altitude' in ecological research. Trends in Ecology \& Evolution 22:569-574. DOI: $10.1016 /$ j.tree.2007.09.006.

Kramer MG, Chadwick OA. 2018. Climate-driven thresholds in reactive mineral retention of soil carbon at the global scale. Nature Climate Change 8:1104-1108. DOI: 10.1038/s41558-018-0341-4.

Lawrence JE, Hornberger GM. 2007. Soil moisture variability across climate zones. Geophysical Research Letters 34. DOI: https://doi.org/10.1029/2007GL031382.

Leonard LT, Mikkelson K, Hao Z, Brodie EL, Williams KH, Sharp JO. 2020a. A comparison of lodgepole and spruce needle chemistry impacts on terrestrial biogeochemical processes during isolated needle decomposition. PeerJ. 8:e9538. DOI: 10.7717/peerj.9538

Leonard LT, Wilmer, C, Steltzer, H, Williams, KH and Sharp, JO. 2020b. Accelerated Snowmelt Protocol to Simulate Climate Change Induced Impacts on Snowpack Dependent Ecosystems. Bio-protocol 10(6): e3557. DOI: 10.21769/BioProtoc.3557.

Liu W, Zhang Z, Wan S. 2009. Predominant role of water in regulating soil and microbial respiration and their responses to climate change in a semiarid grassland. Global Change Biology 15:184-195. DOI: $10.1111 /$ j.1365-2486.2008.01728.x.

Love MI, Huber W, Anders S. 2014. Moderated estimation of fold change and dispersion for RNA-seq data with DESeq2. Genome Biology 15:550. DOI: 10.1186/s13059-014-0550-8.

Lukas J, Barsugli J, Doesken N, Rangwala I, Wolter K. 2014. Climate Change in Colorado a Synthesis to Support Water Resources Management and Adaptation. Cooperative Institute for Research in Environmental Sciences, University of Colorado Boulder.

McMurdie PJ, Holmes S. 2013. phyloseq: An R Package for Reproducible Interactive Analysis and Graphics of Microbiome Census Data. PLOS ONE 8:e61217. DOI: 10.1371/journal.pone.0061217.

Meisner A, Leizeaga A, Rousk J, Bååth E. 2017. Partial drying accelerates bacterial growth recovery to rewetting. Soil Biology and Biochemistry 112:269-276. DOI: 10.1016/j.soilbio.2017.05.016.

Naumann D. 2000. Infrared Spectroscopy in Microbiology. In: Encyclopedia of Analytical Chemistry. John Wiley \& Sons Ltd, Chichester, 102-131.

PeerJ reviewing PDF | (2021:03:59500:2:0:NEW 9 Jul 2021) 
712 Negrón JF, Cain B. 2018. Mountain Pine Beetle in Colorado: A Story of Changing Forests. Journal of

713

714

715

716

717

718

719

720

721

722

723

724

725

726

727

728

729

730

731

732

733

734

735

736

737

738

739

740

741

742

743

744 Forestry. DOI: 10.1093/jofore/fvy032.

Nijs EA de, Hicks LC, Leizeaga A, Tietema A, Rousk J. 2019. Soil microbial moisture dependences and responses to drying-rewetting: The legacy of 18 years drought. Global Change Biology 25:10051015. DOI: https://doi.org/10.1111/gcb.14508.

NPS. 2018.U.S. National Park Service. Available at https://www.nps.gov/romo/learn/nature/climatechange.htm (accessed January 13, 2021).

Ochoa-Hueso R, Collins SL, Delgado-Baquerizo M, Hamonts K, Pockman WT, Sinsabaugh RL, Smith MD, Knapp AK, Power SA. 2018. Drought consistently alters the composition of soil fungal and bacterial communities in grasslands from two continents. Global Change Biology 24:2818-2827. DOI: https://doi.org/10.1111/gcb.14113.

Oksanen J, Blanchet FG, Friendly M, Kindt R, Legendre P, McGlinn D, Minchin PR, O’Hara RB, Simpson GL, Solymos P, Stevens MHH, Szoecs E, Wagner H. 2019. vegan: Community Ecology Package.

Oliverio AM, Bradford MA, Fierer N. 2017. Identifying the microbial taxa that consistently respond to soil warming across time and space. Global Change Biology 23:2117-2129. DOI: 10.1111/gcb.13557.

Özgenç Ö, Durmaz S, Kuştaş S. 2017. Chemical Analysis of Tree Barks using ATR-FTIR Spectroscopy and Conventional Techniques. BioResources 12:9143-9151.

Pandey KK, Pitman AJ. 2003. FTIR studies of the changes in wood chemistry following decay by brownrot and white-rot fungi. International Biodeterioration \& Biodegradation 52:151-160. DOI: 10.1016/S0964-8305(03)00052-0.

Parada AE, Needham DM, Fuhrman JA. 2016. Every base matters: assessing small subunit rRNA primers for marine microbiomes with mock communities, time series and global field samples. Environmental Microbiology 18:1403-1414. DOI: 10.1111/1462-2920.13023.

Peñuelas J, Rico L, Ogaya R, Jump AS, Terradas J. 2012. Summer season and long-term drought increase the richness of bacteria and fungi in the foliar phyllosphere of Quercus ilex in a mixed Mediterranean forest. Plant Biology 14:565-575. DOI: https://doi.org/10.1111/j.14388677.2011.00532.x.

Pruesse E, Peplies J, Glöckner FO. 2012. SINA: Accurate high-throughput multiple sequence alignment of ribosomal RNA genes. Bioinformatics 28:1823-1829. DOI: 10.1093/bioinformatics/bts252.

Rein I von, Gessler A, Premke K, Keitel C, Ulrich A, Kayler ZE. 2016. Forest understory plant and soil microbial response to an experimentally induced drought and heat-pulse event: the importance of 
745

746

747

748

749

750

751

752

753

754

755

756

757

758

759

760

761

762

763

764

765

766

767

768

769

770

771

772

773

774

775

776

777

778

maintaining the continuum. Global Change Biology 22:2861-2874. DOI:

https://doi.org/10.1111/gcb.13270.

Santonja M, Fernandez C, Gauquelin T, Baldy V. 2015. Climate change effects on litter decomposition: intensive drought leads to a strong decrease of litter mixture interactions. Plant and Soil 393:6982. DOI: $10.1007 / \mathrm{s} 11104-015-2471-\mathrm{z}$.

Šantrůčková H, Krištůfková M, Vaněk D. 2006. Decomposition rate and nutrient release from plant litter of Norway spruce forest in the Bohemian Forest. Biologia 61:S499-S508. DOI: 10.2478/s11756007-0073-9.

Schimel JP. 2018. Life in Dry Soils: Effects of Drought on Soil Microbial Communities and Processes. Annual Review of Ecology, Evolution, and Systematics 49:409-432. DOI: 10.1146/annurevecolsys-110617-062614.

Schindlbacher A, Rodler A, Kuffner M, Kitzler B, Sessitsch A, Zechmeister-Boltenstern S. 2011. Experimental warming effects on the microbial community of a temperate mountain forest soil. Soil Biology and Biochemistry 43:1417-1425. DOI: 10.1016/j.soilbio.2011.03.005.

Schlesinger WH, Dietze MC, Jackson RB, Phillips RP, Rhoades CC, Rustad LE, Vose JM. 2016. Forest biogeochemistry in response to drought. Global Change Biology 22:2318-2328. DOI: https://doi.org/10.1111/gcb.13105.

Seidl R, Schelhaas M, Lexer MJ. 2011. Unraveling the drivers of intensifying forest disturbance regimes in Europe. Global Change Biology 17:2842-2852. DOI: 10.1111/j.1365-2486.2011.02452.x.

Shade A, Peter H, Allison SD, Baho D, Berga M, Buergmann H, Huber DH, Langenheder S, Lennon JT, Martiny JB, Matulich KL, Schmidt TM, Handelsman J. 2012. Fundamentals of Microbial Community Resistance and Resilience. Frontiers in Microbiology 3. DOI: 10.3389/fmicb.2012.00417.

Stamps BW, Lyles CN, Suflita JM, Masoner JR, Cozzarelli IM, Kolpin DW, Stevenson BS. 2016. Municipal Solid Waste Landfills Harbor Distinct Microbiomes. Frontiers in Microbiology 7. DOI: $10.3389 /$ fmicb.2016.00534.

Sundqvist MK, Giesler R, Wardle DA. 2011. Within- and Across-Species Responses of Plant Traits and Litter Decomposition to Elevation across Contrasting Vegetation Types in Subarctic Tundra. PLOS ONE 6:e27056. DOI: 10.1371/journal.pone.0027056.

Tashi S, Singh B, Keitel C, Adams M. 2016. Soil carbon and nitrogen stocks in forests along an altitudinal gradient in the eastern Himalayas and a meta-analysis of global data. Global Change Biology 22:2255-2268. DOI: https://doi.org/10.1111/gcb.13234.

Tennant CJ, Harpold AA, Lohse KA, Godsey SE, Crosby BT, Larsen LG, Brooks PD, Kirk RWV, Glenn NF. 2017. Regional sensitivities of seasonal snowpack to elevation, aspect, and vegetation cover

PeerJ reviewing PDF | (2021:03:59500:2:0:NEW 9 Jul 2021) 
779

780

781

782

783

784

785

786

787

788

789

790

791

792

793

794

795

796

797

798

799

800

801

802

803

804

805

806

807

808

809

810

811

812

in western North America. Water Resources Research 53:6908-6926. DOI: https://doi.org/10.1002/2016WR019374.

Thomson BC, Tisserant E, Plassart P, Uroz S, Griffiths RI, Hannula SE, Buée M, Mougel C, Ranjard L, Van Veen JA, Martin F, Bailey MJ, Lemanceau P. 2015. Soil conditions and land use intensification effects on soil microbial communities across a range of European field sites. Soil Biology and Biochemistry 88:403-413. DOI: 10.1016/j.soilbio.2015.06.012.

Torvinen E, Meklin T, Torkko P, Suomalainen S, Reiman M, Katila M-L, Paulin L, Nevalainen A. 2006. Mycobacteria and Fungi in Moisture-Damaged Building Materials. Applied and Environmental Microbiology 72:6822-6824. DOI: 10.1128/AEM.00588-06.

United States Department of Agriculture. Web Soil Survey. Available at http://websoilsurvey.nrcs.usda.gov/ (accessed December 14, 2020).

U.S. Geological Survey. 2005. Mineral Resources Data System: U.S. Geological Survey. Reston, Virginia. Available at https://mrdata.usgs.gov/mrds/. (Accessed February 2, 2021).

Vesterdal L. 1999. Influence of soil type on mass loss and nutrient release from decomposing foliage litter of beech and Norway spruce. Canadian Journal of Forest Research 29:95-105. DOI: 10.1139/x98-182.

de Vries FT, Griffiths RI, Bailey M, Craig H, Girlanda M, Gweon HS, Hallin S, Kaisermann A, Keith AM, Kretzschmar M, Lemanceau P, Lumini E, Mason KE, Oliver A, Ostle N, Prosser JI, Thion C, Thomson B, Bardgett RD. 2018. Soil bacterial networks are less stable under drought than fungal networks. Nature Communications 9:3033. DOI: 10.1038/s41467-018-05516-7.

Wainwright HM, Steefel C, Trutner SD, Henderson AN, Nikolopoulos EI, Wilmer CF, Chadwick KD, Falco N, Schaettle KB, Brown JB, Steltzer H, Williams KH, Hubbard SS, Enquist BJ. 2020. Satellite-derived foresummer drought sensitivity of plant productivity in Rocky Mountain headwater catchments: spatial heterogeneity and geological-geomorphological control. Environmental Research Letters 15:084018. DOI: 10.1088/1748-9326/ab8fd0.

Wilson MA, Burt R, Indorante SJ, Jenkins AB, Chiaretti JV, Ulmer MG, Scheyer JM. 2008. Geochemistry in the modern soil survey program. Environmental Monitoring and Assessment 139:151-171. DOI: 10.1007/s10661-007-9822-z.

Wipf S, Rixen C, Mulder CPH. 2006. Advanced snowmelt causes shift towards positive neighbour interactions in a subarctic tundra community. Global Change Biology 12:1496-1506. DOI: 10.1111/j.1365-2486.2006.01185.x.

Wu Z, Dijkstra P, Koch GW, Peñuelas J, Hungate BA. 2011. Responses of terrestrial ecosystems to temperature and precipitation change: a meta-analysis of experimental manipulation. Global Change Biology 17:927-942. DOI: 10.1111/j.1365-2486.2010.02302.x.

PeerJ reviewing PDF | (2021:03:59500:2:0:NEW 9 Jul 2021) 
813 Yang N, Butenschoen O, Rana R, Köhler L, Hertel D, Leuschner C, Scheu S, Polle A, Pena R. 2019. Leaf 814 litter species identity influences biochemical composition of ectomycorrhizal fungi. Mycorrhiza 815 29:85-96. DOI: 10.1007/s00572-018-0876-2.

816 Zhou C, Liu Y, Liu C, Liu Y, Tfaily MM. 2019. Compositional changes of dissolved organic carbon

817 during its dynamic desorption from hyporheic zone sediments. Science of the Total Environment $818 \quad 658: 16-23$.

819 Zhu J, Yang W, He X. 2013. Temporal Dynamics of Abiotic and Biotic Factors on Leaf Litter of Three 820 Plant Species in Relation to Decomposition Rate along a Subalpine Elevation Gradient. PLOS 821 ONE 8:e62073. DOI: 10.1371/journal.pone.0062073.

822 
Figure 1

Experimental design, plot, and schedule.

(A) The schematic of the ring deployment, (B) plot layout, and (C) sampling timeline are provided. Four replicate collars for each sample type were deployed in Fall 2016. In October of 2017, one of each sample quadruplicate was sacrificed to inform additional studies published elsewhere (Leonard et al., 2020a).

\begin{tabular}{|c|c|c|c|}
\hline A. Needle Ring Deployment & B. Plot layout & & C. Deployment and Sampling Timeline \\
\hline 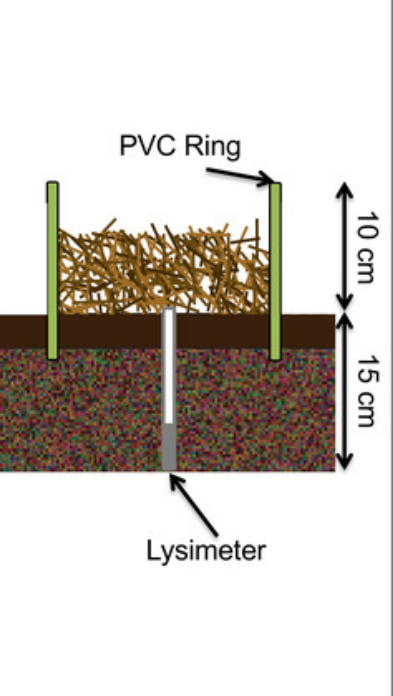 & $\begin{array}{l}\text { Upper } \\
\text { Upper } \\
\text { Subalpine: } \\
3,500 \mathrm{~m} \\
\text { Middle-ES } \\
\text { Lower } \\
\text { Subalpine: } \\
3,100 \mathrm{~m} \\
\text { Middle } \\
\text { Lower } \\
\text { Subalpine: } \\
\text { 3,100 m } \\
\text { Lower } \\
\text { Lower } \\
\text { Montane: } \\
2,800 \mathrm{~m}\end{array}$ & $\begin{array}{l}250 \mathrm{~g} \text { Spruce } \\
250 \mathrm{~g} \text { Lodgepole } \\
\text { Needle-free } \\
\text { Control } \\
\square \text { Early } \\
\text { Snowmelt }\end{array}$ & 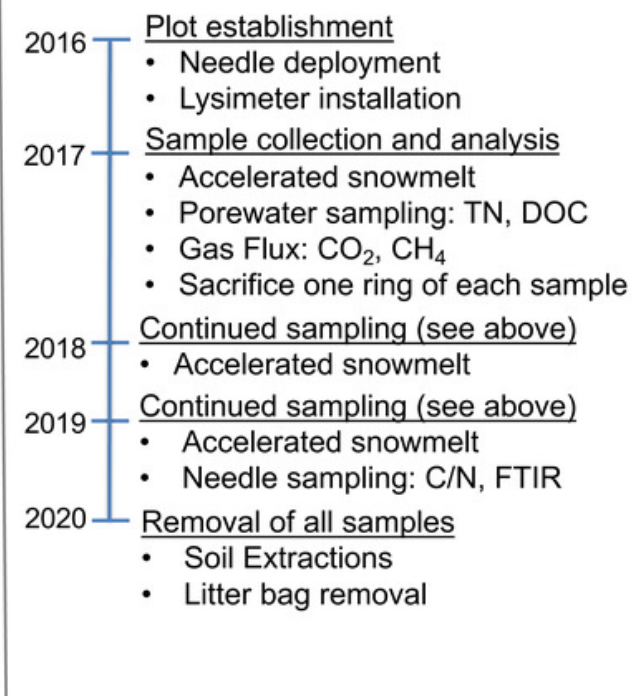 \\
\hline
\end{tabular}


Figure 2

Seasonal soil temperature and moisture data across the three study years.

Climate data is shown for the three study years with soil moisture and temperature data from the Lower $(2,800 \mathrm{~m})$ and Middle $(3,100 \mathrm{~m})$ locations. The Upper plot data is not shown but is provided in Figure S2. Arrows indicate specific sampling events conducted as indicated in black (gas flux), grey (DNA \& gas flux), and orange (DNA).

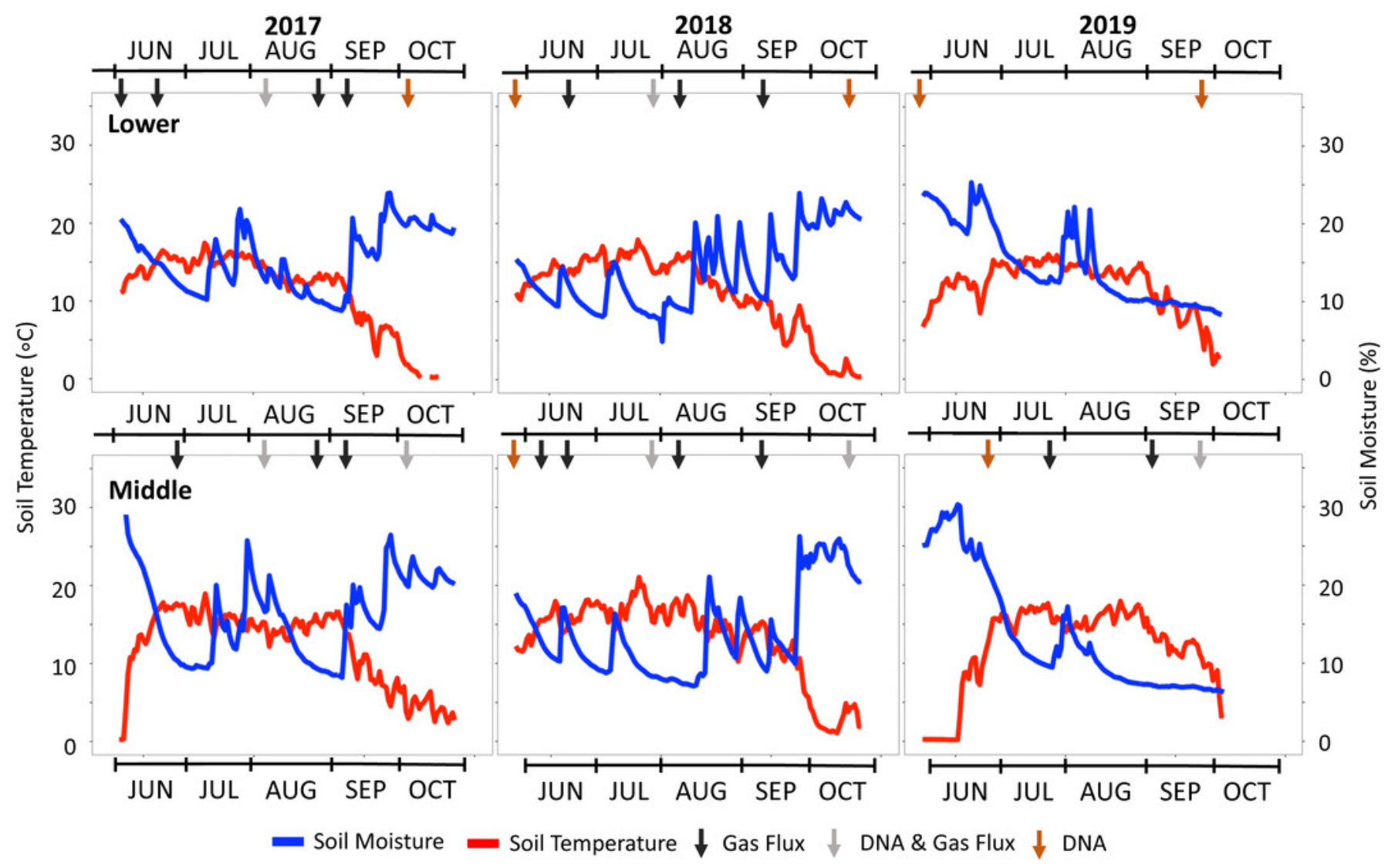




\section{Table 1 (on next page)}

Climate variable shifts across each study water year. 


\begin{tabular}{|c|c|c|c|c|}
\hline $\begin{array}{c}\text { Water Year } \\
\text { (Oct-Sep) }\end{array}$ & Dry Soil $^{*}$ & Hot Days $^{* *}$ & $\begin{array}{c}\text { Total } \\
\text { Precipitation } \\
\text { (cm SWE) }\end{array}$ & $\begin{array}{c}\text { Snow } \\
\text { (cm SWE) }\end{array}$ \\
\hline 2017 & 143 & 73 & 94 & 61 \\
\hline 2018 & 163 & 88 & 48 & 31 \\
\hline 2019 & 44 & 69 & 88 & 63 \\
\hline $\begin{array}{c}\text { AVG } \\
(\mathbf{1 9 9 0 - 2 0 1 0 )}\end{array}$ & $\mathbf{1 3 2} \pm \mathbf{9 0}$ & $\mathbf{7 0} \pm \mathbf{2 7}$ & $\mathbf{8 0} \pm \mathbf{1 5}$ & $\mathbf{4 8} \pm \mathbf{1 4}$ \\
\hline
\end{tabular}

1 Data from the Butte 380 USDA SNOTEL station.

$2{ }^{*}$ Total days the daily maximum soil moisture was less than $10 \%$ water at $20 \mathrm{~cm}$ depth. Data was available starting in 2006, thus the average is 2006-2016.

${ }^{* *}$ Total days the daily maximum temperature was greater than $20^{\circ} \mathrm{C}$. 
Figure 3

$\mathrm{C}: \mathrm{N}$ ratios decreased over the three-year study period across elevations.

Carbon:Nitrogen ratios (C:N) are shown across each elevation for (A) Spruce and (B) Lodgepole needle decomposition. The harvested 2016 needle values are shown first, followed by the 2019 decomposed Lower, Middle, and Upper plots.

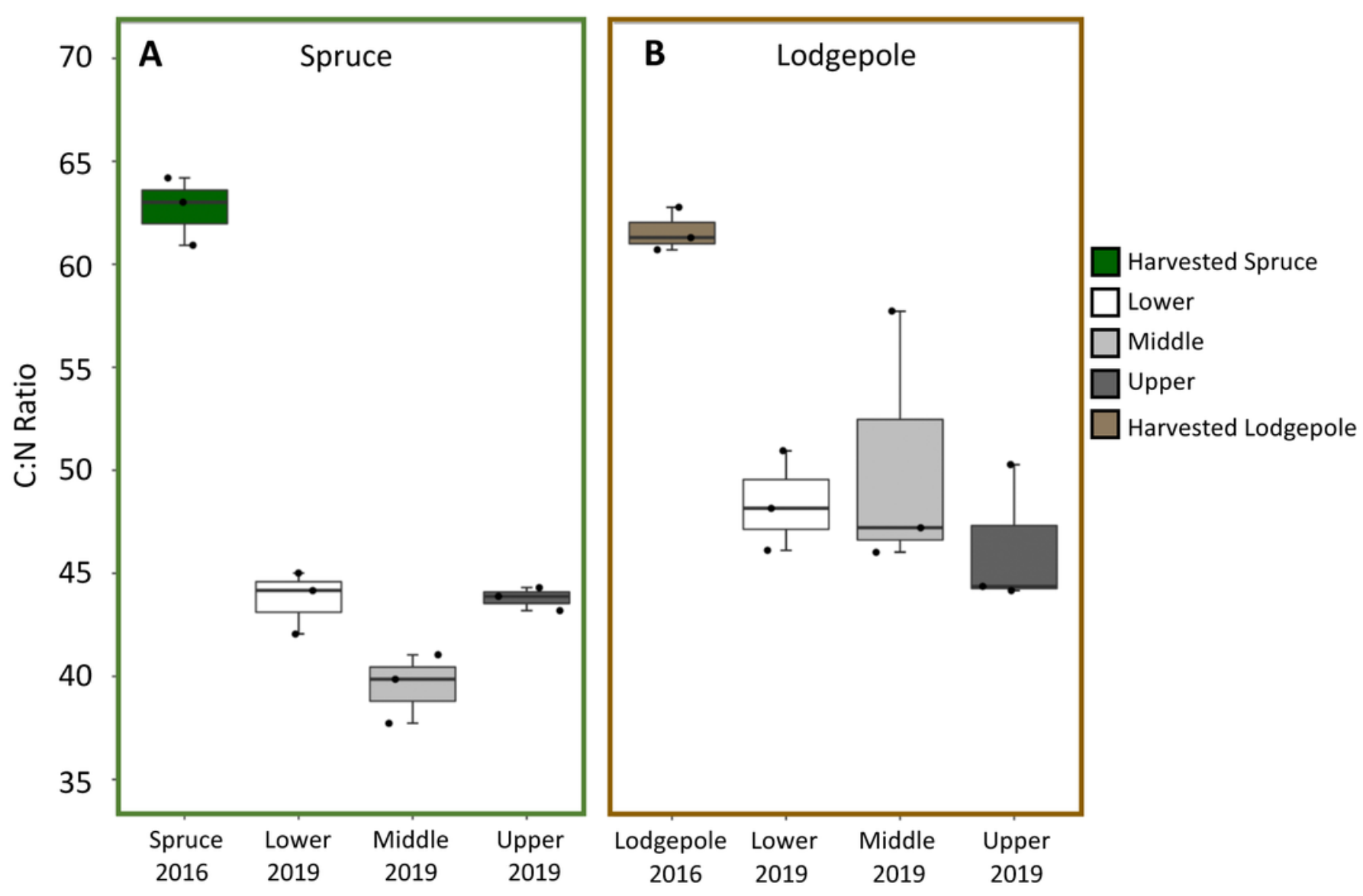


Figure 4

Compilation of gas flux, porewater, and soil extractions across experimental elevation plots.

Averages of soil porewater and gas flux measurements for each elevation $(n=3)$. Only control values are shown to remove needle decomposition biases.

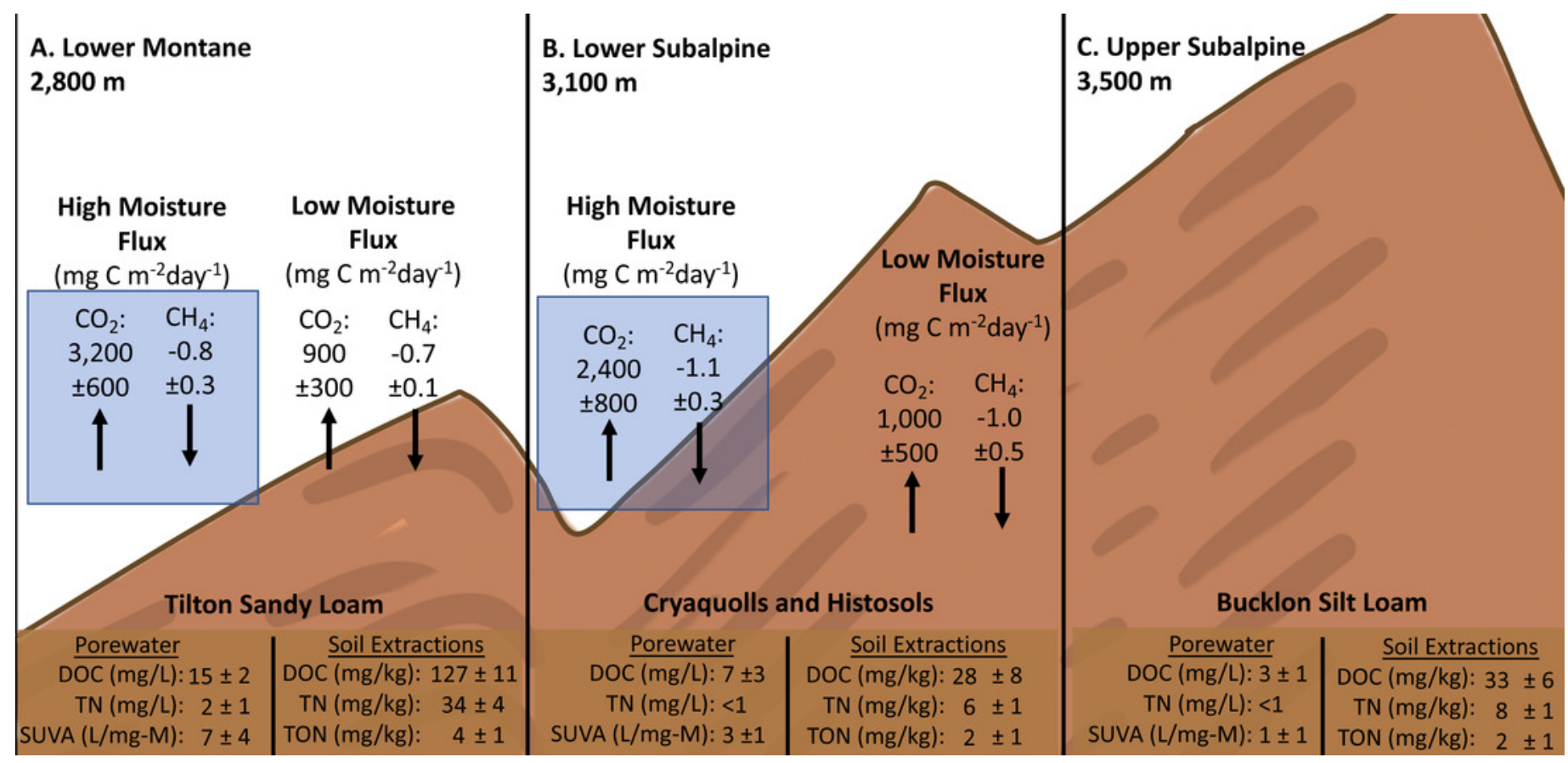




\section{Figure 5}

Higher organic carbon porewater concentrations are associated with the early snowmelt plot in contrast to the control snowmelt plot.

2017-2019 porewater DOC concentrations were collected for both the Lower Subalpine control (Middle) and early snowmelt (Middle-ES) plots for the control, spruce, and lodgepole samples. Error bars indicate plus or minus one standard deviation. Samples were collected during two consecutive days from both plots in 2017-2018 to increase the sample size $(n=3-6)$. 


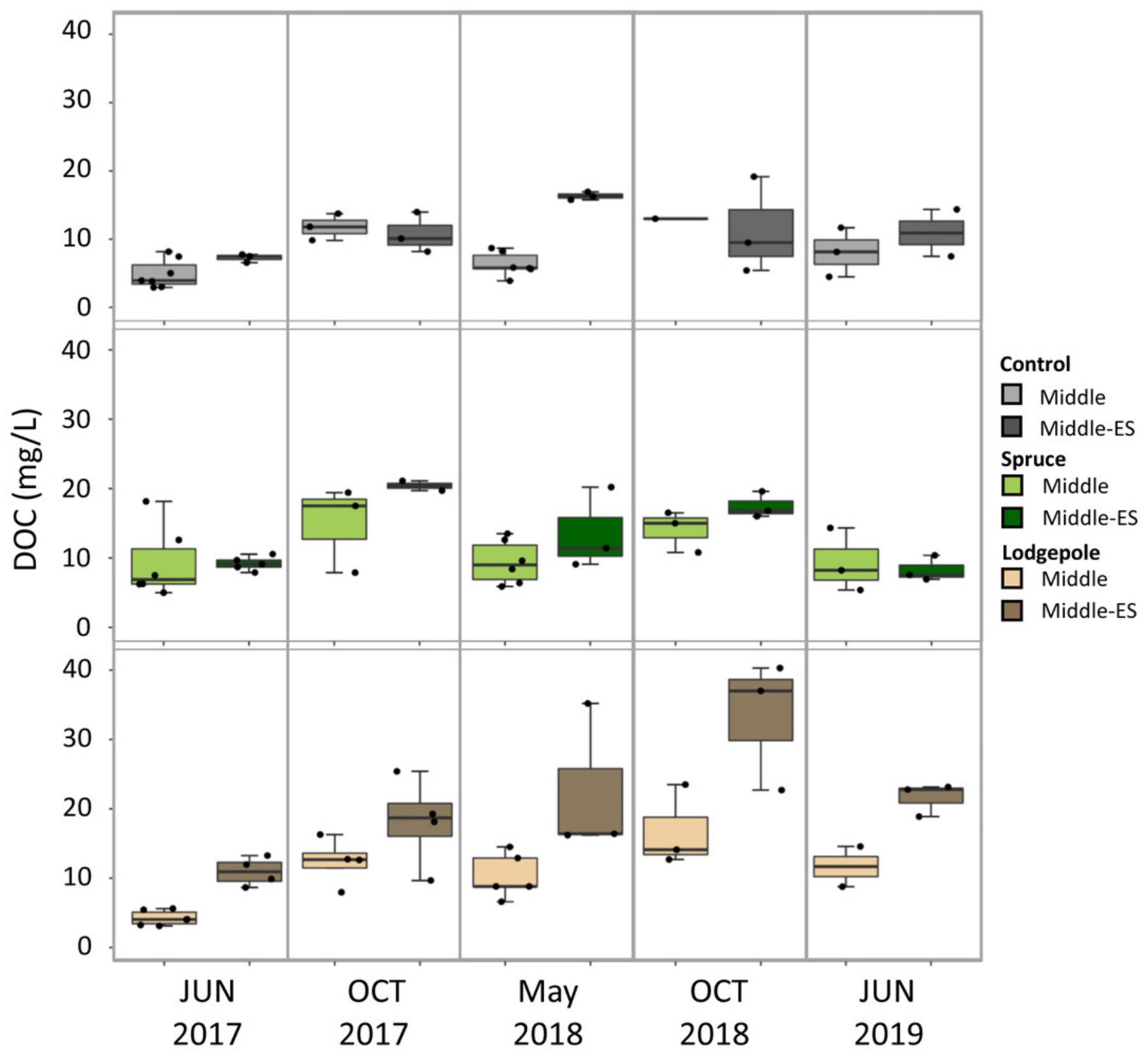




\section{Table 2 (on next page)}

Soil extractions across elevation and samples.

Concentrations of DOC (dissolved organic carbon), TN (total dissolved nitrogen), and TON (total dissolved organic nitrogen) across elevations in August $2020(n=3)$. 


\begin{tabular}{|c|c|c|c|c|c|c|c|c|c|c|c|c|}
\hline & \multicolumn{3}{|c|}{ Lower } & \multicolumn{3}{|c|}{ Middle } & \multicolumn{3}{|c|}{ Middle-ES } & \multicolumn{3}{|c|}{ Upper } \\
\hline & Control & Spruce & Lodge & Control & Spruce & Lodge & Control & Spruce & Lodge & Control & Spruce & Lodge \\
\hline $\begin{array}{r}\text { DOC } \\
(\mathrm{mg} / \mathrm{kg})\end{array}$ & $\begin{array}{c}127 \\
( \pm 11)\end{array}$ & $\begin{array}{c}183 \\
( \pm 39)^{*}\end{array}$ & $\begin{array}{c}171 \\
( \pm 18)\end{array}$ & $\begin{array}{c}28 \\
( \pm 8)\end{array}$ & $\begin{array}{c}68 \\
( \pm 34)\end{array}$ & $\begin{array}{c}115 \\
( \pm 41)\end{array}$ & $\begin{array}{c}32 \\
( \pm 3)\end{array}$ & $\begin{array}{c}54 \\
( \pm 7)\end{array}$ & $\begin{array}{c}94 \\
( \pm 11)\end{array}$ & $\begin{array}{c}33 \\
( \pm 6)\end{array}$ & $\begin{array}{c}56 \\
( \pm 16)\end{array}$ & $\begin{array}{c}92 \\
( \pm 21)\end{array}$ \\
\hline $\begin{array}{r}\mathrm{TN} \\
(\mathrm{mg} / \mathrm{kg})\end{array}$ & $\begin{array}{c}34 \\
( \pm 4)\end{array}$ & $\begin{array}{c}33 \\
( \pm 19)^{*}\end{array}$ & $\begin{array}{c}24 \\
( \pm 7)\end{array}$ & $\begin{array}{c}6 \\
( \pm 1)\end{array}$ & $\begin{array}{c}11 \\
( \pm 9)\end{array}$ & $\begin{array}{c}7 \\
( \pm 3)\end{array}$ & $\begin{array}{c}6 \\
( \pm 1)\end{array}$ & $\begin{array}{c}5 \\
( \pm 1)\end{array}$ & $\begin{array}{c}4 \\
( \pm 1)\end{array}$ & $\begin{array}{c}8 \\
( \pm 1)\end{array}$ & $\begin{array}{c}9 \\
( \pm 3)\end{array}$ & $\begin{array}{c}16 \\
( \pm 16)\end{array}$ \\
\hline $\begin{array}{r}\mathrm{TON} \\
(\mathrm{mg} / \mathrm{kg})\end{array}$ & $\begin{array}{c}4 \\
( \pm 1)\end{array}$ & $\begin{array}{c}4 \\
( \pm 2)^{*}\end{array}$ & $\begin{array}{c}5 \\
( \pm 2)\end{array}$ & $\begin{array}{c}2 \\
( \pm 1)\end{array}$ & $\begin{array}{c}4 \\
( \pm 3)\end{array}$ & $\begin{array}{c}5 \\
( \pm 2)\end{array}$ & $\begin{array}{c}2 \\
( \pm 0)\end{array}$ & $\begin{array}{c}2 \\
( \pm 1)\end{array}$ & $\begin{array}{c}3 \\
( \pm 1)\end{array}$ & $\begin{array}{c}2 \\
( \pm 1)\end{array}$ & $\begin{array}{c}1 \\
( \pm 2)\end{array}$ & $\begin{array}{c}1 \\
( \pm 1)\end{array}$ \\
\hline
\end{tabular}




\section{Figure 6}

$\mathrm{CO}_{2}$ production is influenced by seasonal shifts in temperature and moisture, but not elevation.

$\mathrm{CO}_{2}$ flux measurements over the snow-free months of 2017-2018 for the (A, B) control and (C, D) lodgepole samples across elevation and snowmelt manipulations. The 2019 full data and spruce samples are not shown but can be found in Figures S5 and S6. (E, F) air temperature and total precipitation are shown from the Butte $380 \operatorname{SNOTEL~}(3,100 \mathrm{~m})$ database. Error bars indicate plus or minus one standard deviation. 


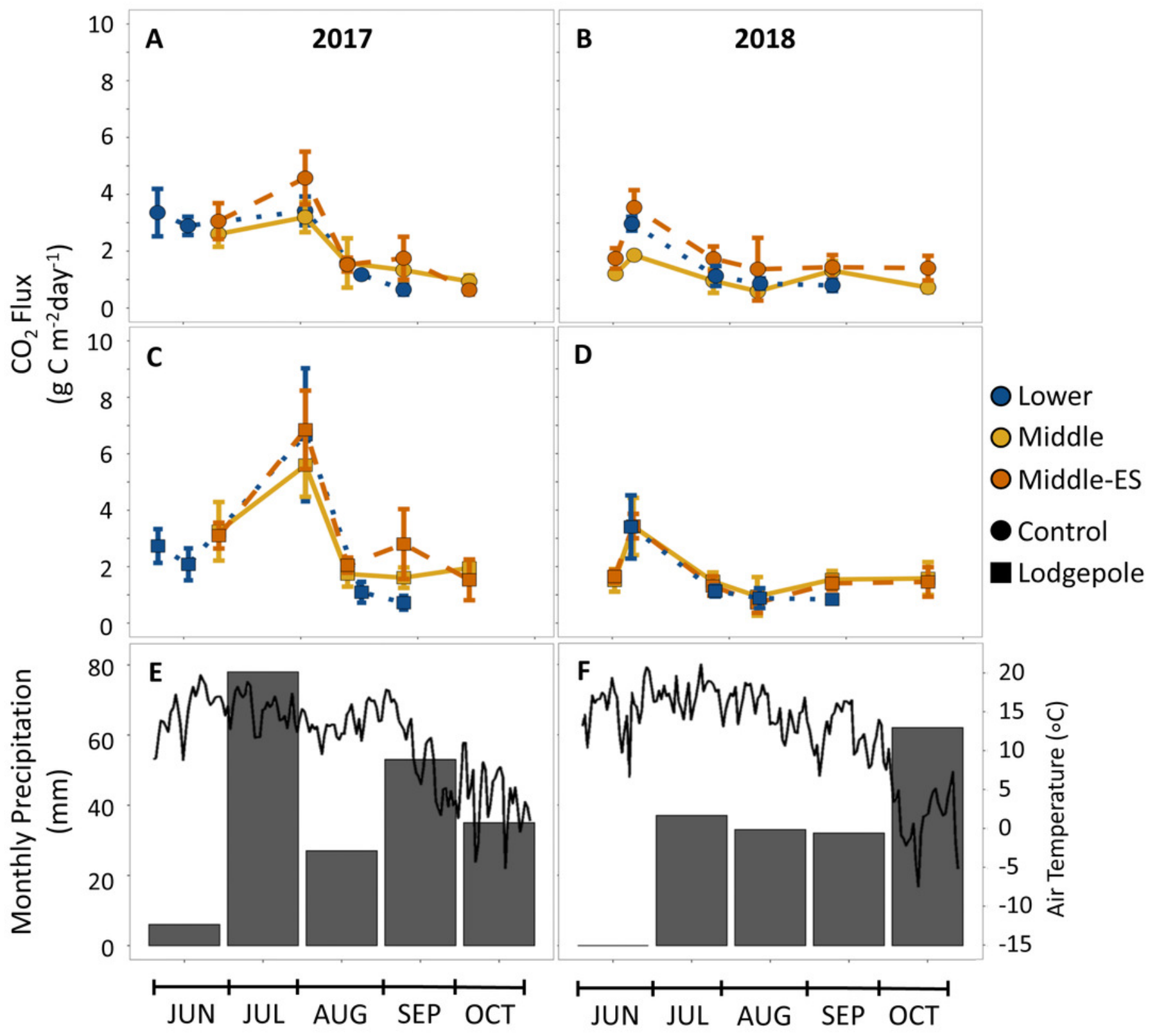




\section{Figure 7}

Average alpha diversity richness increased in the summer dry period of 2018.

Species richness changes over time at the (A, C, E) Lower and (B, D, F) Middle plots for the $(A, B)$ controls and $(C, D)$ needle samples. The average daily soil temperature and moisture are shown in red and blue for the (E) Lower and (F) Middle plots on each sample date. The Upper plot is not shown but can be found in Figure S9. Error bars indicate plus or minus one standard deviation $(n=3,4)$. Note a lack of error bars for a sample point is due to $n<3$ caused by sample removal during rarefaction. 


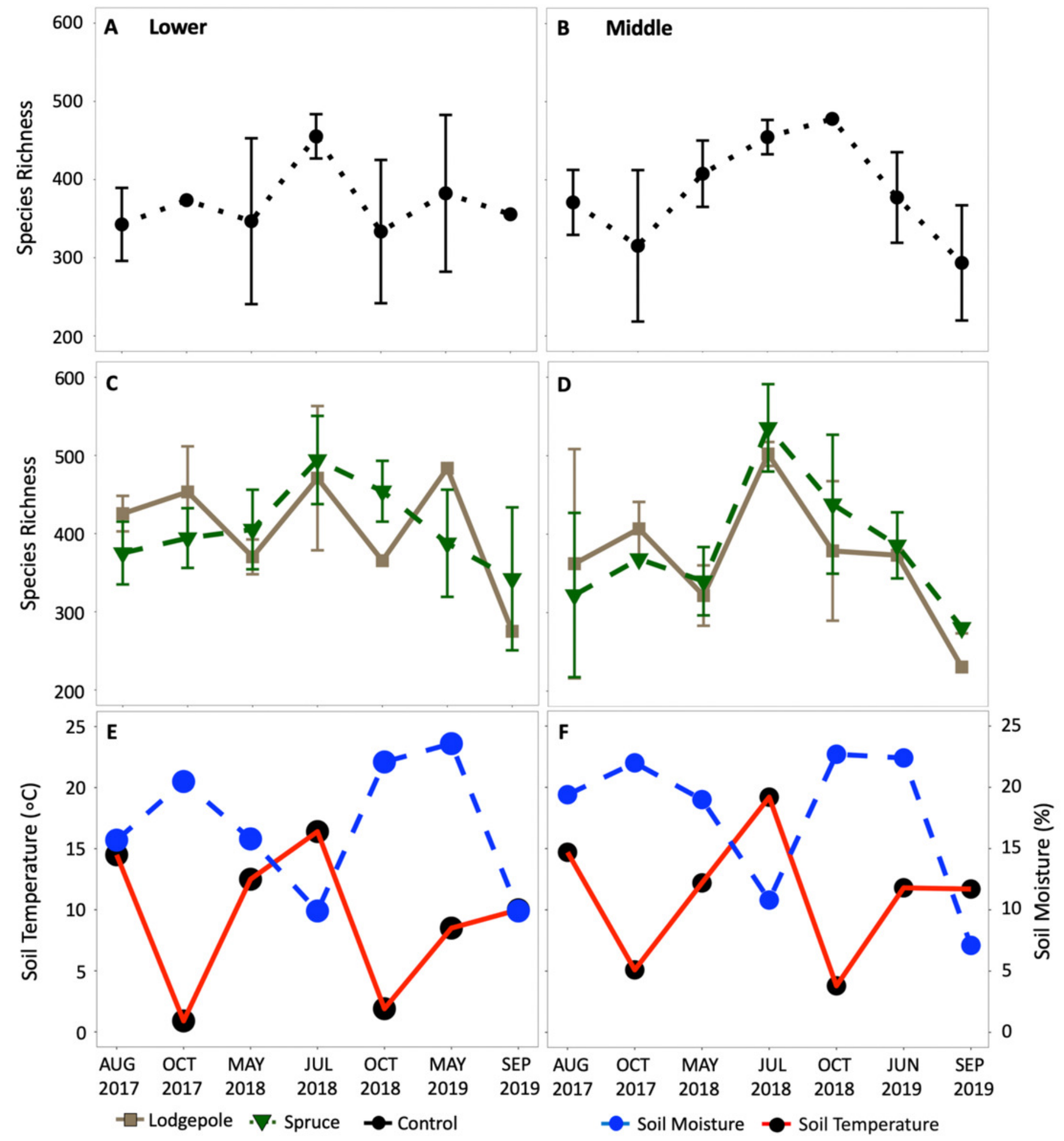




\section{Figure 8}

Bacterial communities cluster significantly as a function of date and environmental variables.

Canonical correspondence analysis of environmental variables drive beta diversity community clustering as a function of soil temperature and moisture over time at the (A) Lower, (B) Middle, and (C) Middle-ES plots. Soil moisture and temperature are values unique to each plot from the microclimate sensors on the day of collection. Precipitation represents monthly totals from the Butte 380 SNOTEL $(3,100 \mathrm{~m})$ database.

*The Lower samples were collected in May 2019, and Middle in June 2019.
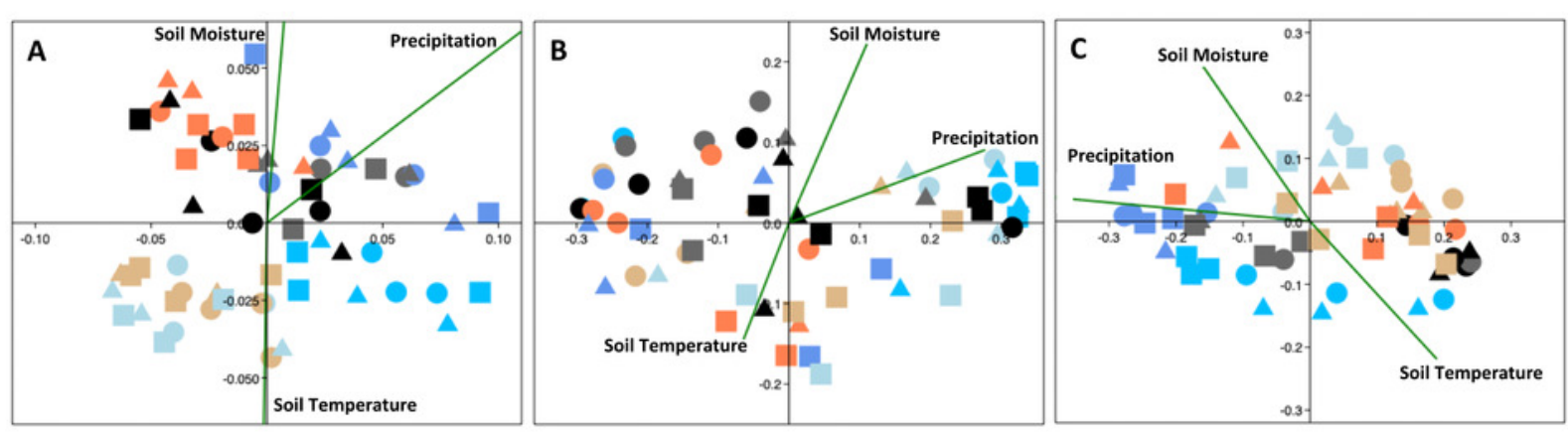

Date

AUG 2017

- OCT 2017

- MAY 2018

- JUL 2018

- OCT 2018

- MAY/ JUN 2019*

- SEP 2019

Sample

- Control

- Lodgepole

A Spruce 